\title{
ESPAÇOS LIVRES
}

SILVIO SOARES MACEDO

\section{RESUMO}

O texto apresenta um painel sobre os conceitos básicos que dirigem o entendimento do paisagismo urbano, tendo como elemento de referência os espaços livres. Discute-se a questão das áreas verdes, das áreas de circulação, da qualificacão dos espaços livres e da composição de suas estruturas morfológicas e de alguns dos principais padrões de organização espacial das cidades brasileiras contemporâneas - das quadras, jardins às áreas verticalizadas.

\section{ABSTRACT}

This paper focuses some of the basic concepts about urban landscape design. The main subject is the urban open spaces their quality patterns and their morfologycal structures.

\section{INTRODUÇÃO}

Este texto é resultado de uma cobrança que me fiz sobre a questão dos espaços livres urbanos, dos quais muito falo e pouco escrevo, tendo já proferido inúmeras aulas e palestras sobre 0 assunto.

O meu laboratório de estudo tem sido a cidade brasileira, em especial a cidade de São Paulo, da qual há mais de uma década venho analisando e discutindo com meus alunos exemplos de constituição, uso e produção dos espaços livres de edificação. Com estes muito aprendi e aumentei minha curiosidade de pesquisador e professor sobre as questōes do paisagismo urbano, sobre as quais desenvolvo grande parte de minha atividade de pesquisa.

\section{CONCEITOS}

Espaços livres - muitas são as acepções que podem ser dadas a este conjunto de palavras, que são utilizadas indistintamente pelos mais diversos grupos sociais para se referir ora a ruas, ora a jardins ou até mesmo e exclusivamente às áreas de lazer. 
Podemos, de um modo preciso, definir espaços livres como todos aqueles não contidos entre as paredes e tetos dos edifícios construídos pela sociedade para sua moradia e trabalho $^{1}$

No contexto urbano tem-se como espaços livres todas as ruas, praças, largos, pátios, quintais, parques, jardins, terrenos baldios, corredores externos, vilas, vielas e outros mais por onde as pessoas fluem no seu dia-a-dia em direção ao trabalho, ao lazer ou à moradia ou ainda exercem atividades específicas tanto de trabalho, como lavar roupas (no quintal ou no pátio), consertar carros, etc., como de lazer (na praça, no play-ground, etc. $)^{2}$.

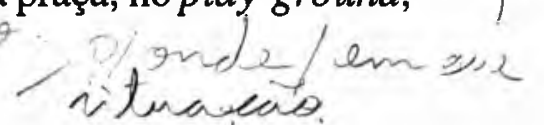

A estes espaços dentro do tecido urbano, contidos dentro dos limites de cada ćidade, vila ou metrópole denominamos espaços livres de edificação e aqueles inseridos nos territórios não ocupados por urbanização denominamos espaços livres de urbanização.

Tem sido comum o uso dúbio do conceito área verde com o de espaço livre, aproveitando-se para tal uma série de idéias consagradas no imaginário popular, que as associa exclusivamente ao lazer. Este ideário associa na existência simples de áreas vegetadas ou ajardinadas dentro do urbano, a possibilidade de seu uso exclusivo e imediato para o lazer.

Estas duas definições de espaços livres, derivadas de um arcabouço conceitual sintetizado e desenvolvido por Miranda M. Magnoli na década de 80, são fundamentais para que se elimine de vez a grande confusão existente sobre o assunto e, a partir deles, outros tantos conceitos poderão ser claramente definidos ${ }^{3}$.

A partir destas idéias determinam-se os limites de conceitos como áreas verdes, áreas de lazer, espaços verdes e áreas de circulação e que designam apenas determinados tipos de espaço livre de edificação e urbanização.

Estas denominações, na realidade, englobam dentro do seu contexto apenas alguns tipos de espaços livres que seriam:

ESPACOS VERDES- Toda área urbana ou porção do território ocupada por qualquer tipo de vegetacão e que tenham um valor social. Neles estão contidos bosques, campos, matas, jardins, alguns tipos de praças e parques, etc. enquanto que terrenos devolutos e quetais não são necessariamente incluídos neste rol. $O$ valor social atribuído pode ser vinculado ao seu utilitarismo em termos de área de produção de alimentos, ao interesse para a conservação ou preservacão de conjuntos de ecossistemas ou mesmo de um único ecossistema, ao seu valor estético/cultural e mesmo a sua destinação para o lazer ativo ou passivo.

ÁREA VERDE - Basicamente refere-se aos mesmos elementos referenciados anteriormente e ainda designam toda e qualquer área onde por um motivo qualquer exista 
vegetação. Este termo também é comumente utilizado para denominar o conjunto de áreas de lazer público de uma cidade, englobando praças, parques, hortos e bosques. Não considero esta última denominação precisa, pois é sabido que nem todas as praças são áreas de lazer e/ou necessitam ser ajardinadas para desempenhar seu papel de espaço social. A utilização do termo sistema de espaços livres públicos de lazer e/ou conservaça é erecisa e objetiva e evita o uso irresponsável do conceito para os mais diversos fins (políticos e quetais).

Este fato está vinculado diretamente a um hipotético índice de $12 \mathrm{~m}^{2} /$ habitante, que teria sido considerado pela ONU - Organização das Nações Unidas, como o padrão ideal de áreas de lazer/vegetação para qualquer cidade. Não se tem notícia da veracidade de tal índice ${ }^{4}$ e mesmo que este ou qualquer outro fosse definido, não teria valor algum, se não fosse associado a critérios de distribuição e acessibilidade, específicos para cada cidade ou lugar.

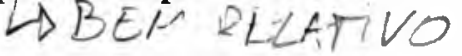

O uso irrestrito e irresponsável deste índice, como referência, tem levado a se considerar canteiros centrais de avenidas ou rotatórias como elementos do sistema urbano de áreas verdes de lazer/colocando-os no mesmo pé de igualdade de praças ou parques. $\rightarrow$ NODEMSER COIJ DE. POS ES:

Onde se localizam, que porte, que forma de acessibilidade e sobre qual suporte físico se instalam as áreas verdes são os parâmetros ideais para a localização e distribuição de tais áreas. Estes devem então ser os critérios básicos para sua formalização.

Os esquemas, hipotéticos, a seguir, mostram algumas situações possíveis de distribuição de áreas verdes em um contexto urbano e o seu grau de eficiência (em todos a área verde tem a mesma dimensão).
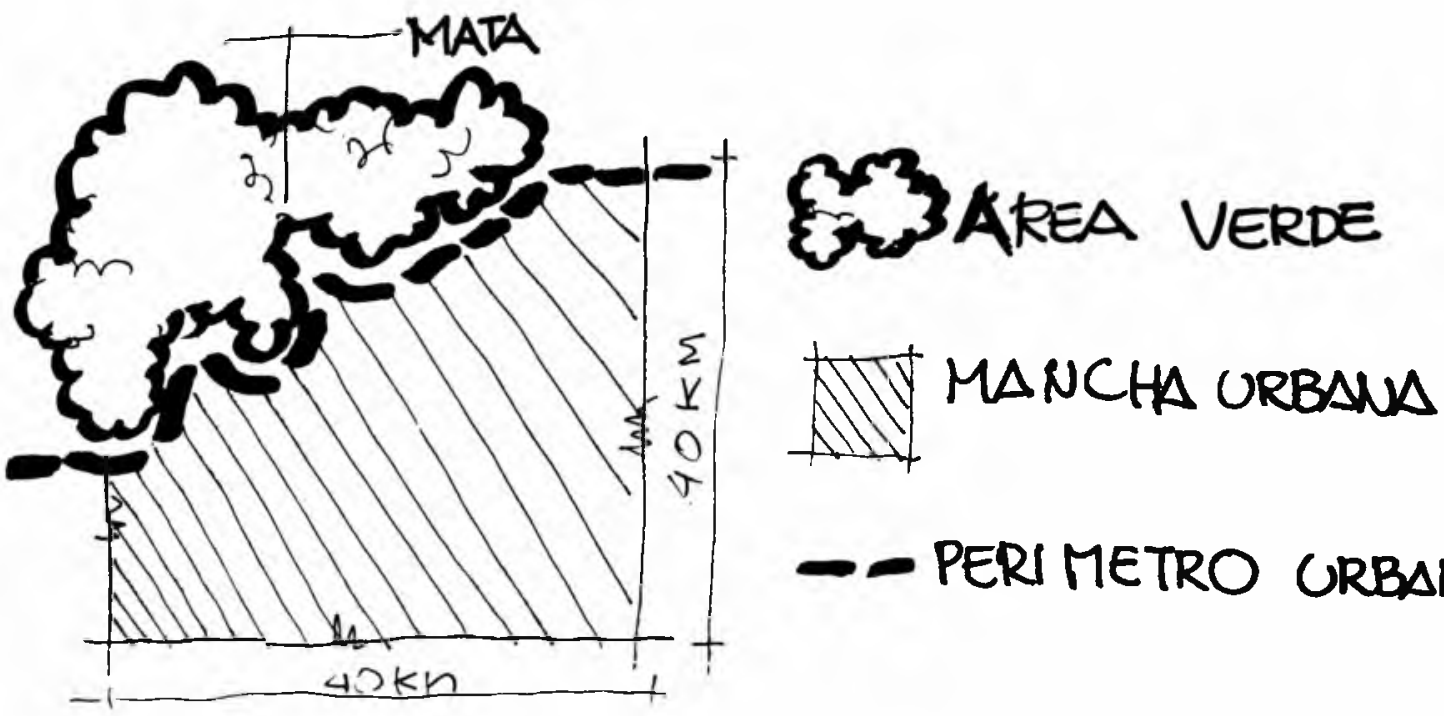

- PERI METRO GRBANO

Uma única área verde de porte existe e está situada na periferia da mancha urbana em uma região montanhosa de altas declividades. Neste caso poucas pessoas, guardas 
florestais, excursionistas, etc., podem acessar a área, que apesar de ser lindeira à parte da cidade, apresenta barreiras reais, em termos de acesso, a maioria da população, que geralmente não costuma e não gosta de se aventurar por terrenos íngremes e florestados.
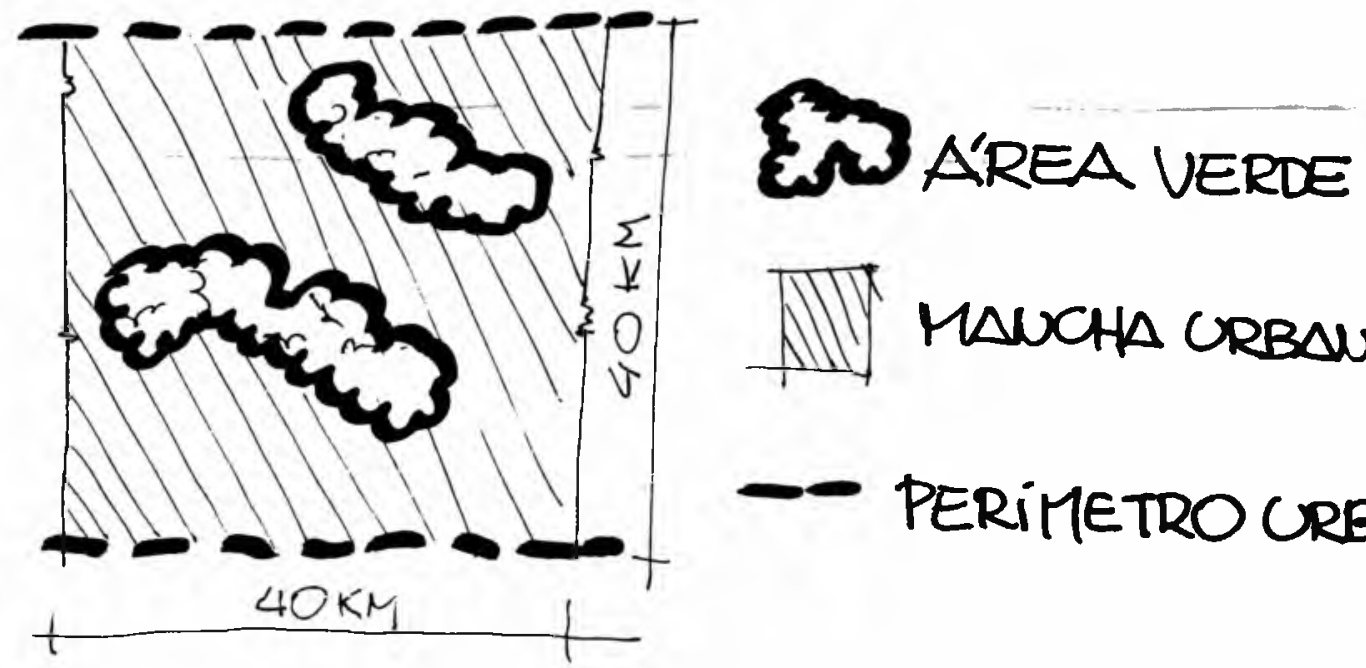

\section{MANCHA CRBANA}

- PERIMETRO CRBANO

A área verde está fragmentada em sete partes iguais, distribuída por todo o tecido urbano de um modo homogêneo. No caso todas as áreas verdes estão situadas em terrenos mais ou menos planos e são de fácil penetração e acesso ao usuário Apesar de possuir a mesma quantidade de área verde que o exemplo 02, esta situaçao privilegia igualitariamente todos os moradores tanto em termos de acessibilidade, quanto de distribuição.

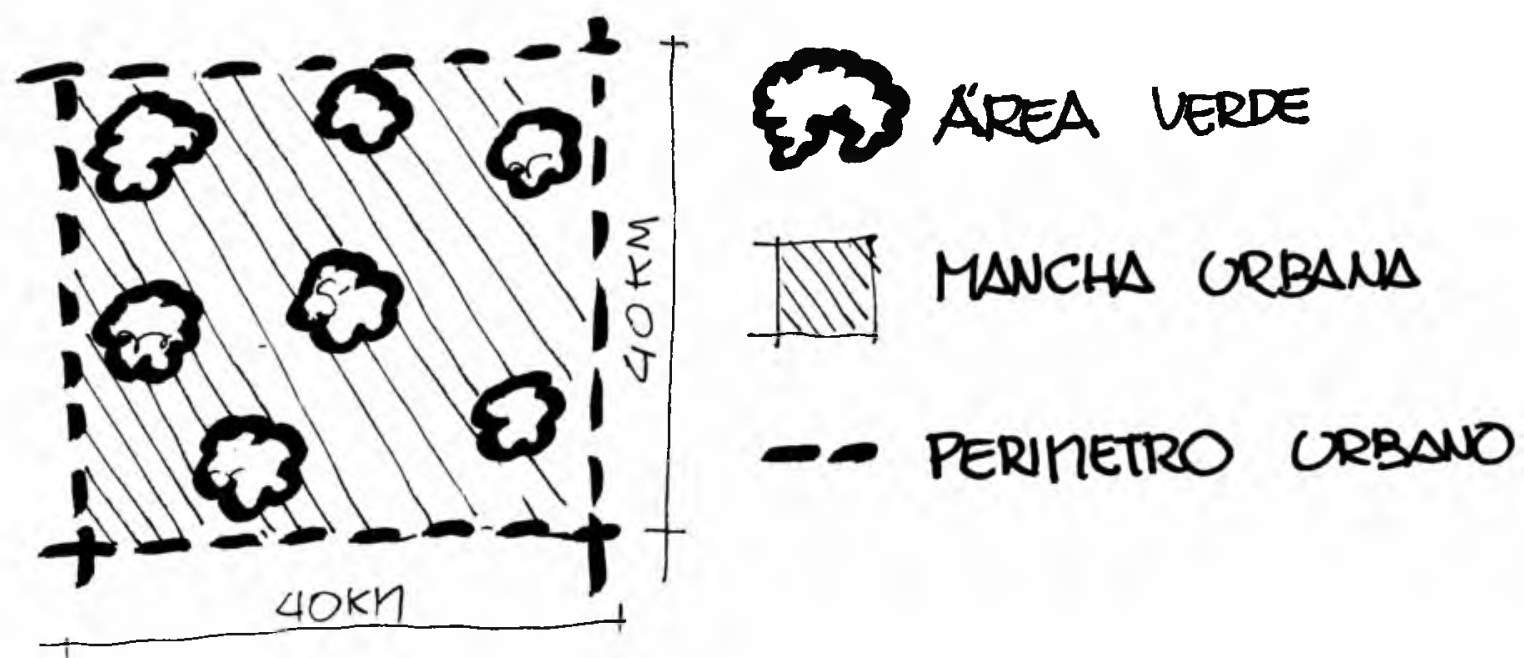

Tem-se também a mesma área verde dos casos anteriores distribuída em dois grandes parques planos lineares e que cortam todo o tecido urbano, sendo acessíveis por todos, em qualquer época. 
Todos os casos apresentam a mesma área verde, só que com certeza os exemplos $02 \mathrm{e}$ 03 apresentam-se muito mais convenientes, pela forma de distribuição e acessibilidade de seus espaços, em termos de lazer urbano, que o exemplo 01, que possui na realidade, apenas uma excelente área de conservação de mata e de encostas.

Os parâmetros aplicados para a análise dos exemplos hipotéticos podem ser transpostos para qualquer aglomerado urbano. A cidade de São Paulo, um exemplo real, apesar de possuir um número significativo de parques (mais de quarenta unidades), um sem número de praças e extensas áreas ocupadas por bairros-jardins não é com certeza um modelo a ser seguido de distribuição de áreas verdes.

O Mapa 01 mostra a localização de todos os parques urbanos, que se concentram em sua maioria nas zonas sul, sudoeste e nordeste, sendo apesar do número relativo, pouco e mal distribuídos para o todo urbano.
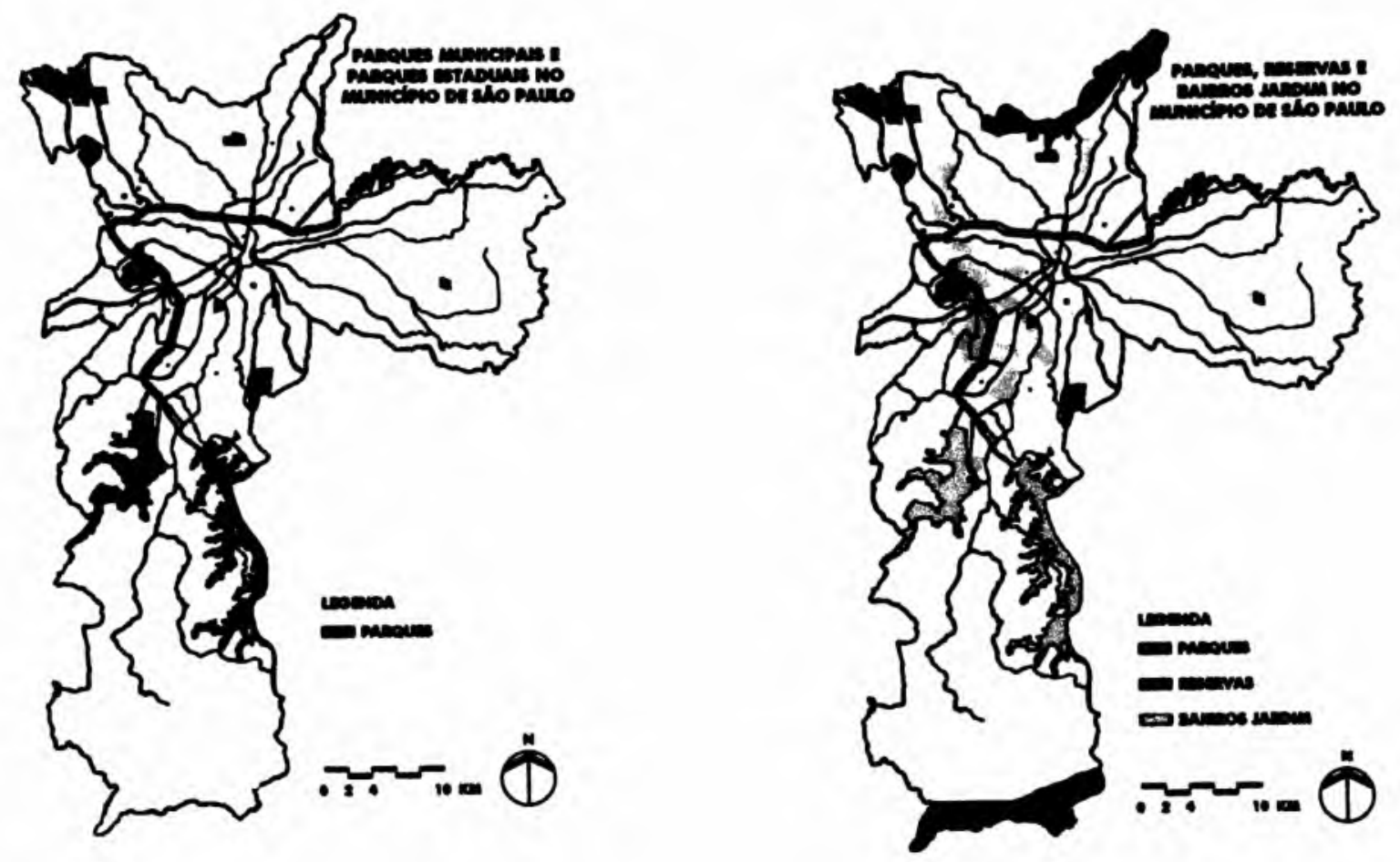

O Mapa 02 inclui além dos parques as áreas verdes pertencentes ao Parque Estadual da Cantareira e aquelas inseridas dentro dos bairros-jardins. A partir deste segundo mapa percebe-se que em termos de áreas plantadas, as zonas sul e norte possuem uma grande quantidade em termos percentuais de "verde" que se convertidos em índices em muito extrapolam os tais $12 \%$.

O que se tem é que tais espaços não são realmente acessíveis à grande massa da população, situando-se em encostas ou pertencendo a jardins particulares ${ }^{5}$. 
Conclui-se então que o conceito fáreas verdes deve assumir um só significado, o de designar toda e qualquer área plantada, tendo um significado social expressivo ou não; e não deve ser associado a espaços de conservação ou lazer que devem ter denominação específica.

ÁREAS DE LAZER - Todo e qualquer espaço livre de edificação destinado prioritariamente ao lazer, seja ele ativo, isto é uma área para jogos e brincadeiras ou contemplativo, isto é áreas dotadas de um valor cênico/paisagístico expressivo em cujo intenor o cidadão apenas passeia a pé. montado ou de carro, contemplando o cenário que se descortina ante seus olhos. Todos os parques, praias e praças urbanos estão englobados dentro deste conceito, possibilitando por muitas vezes uma utilização mista, tanto para o lazer ativo, como para o passivo.

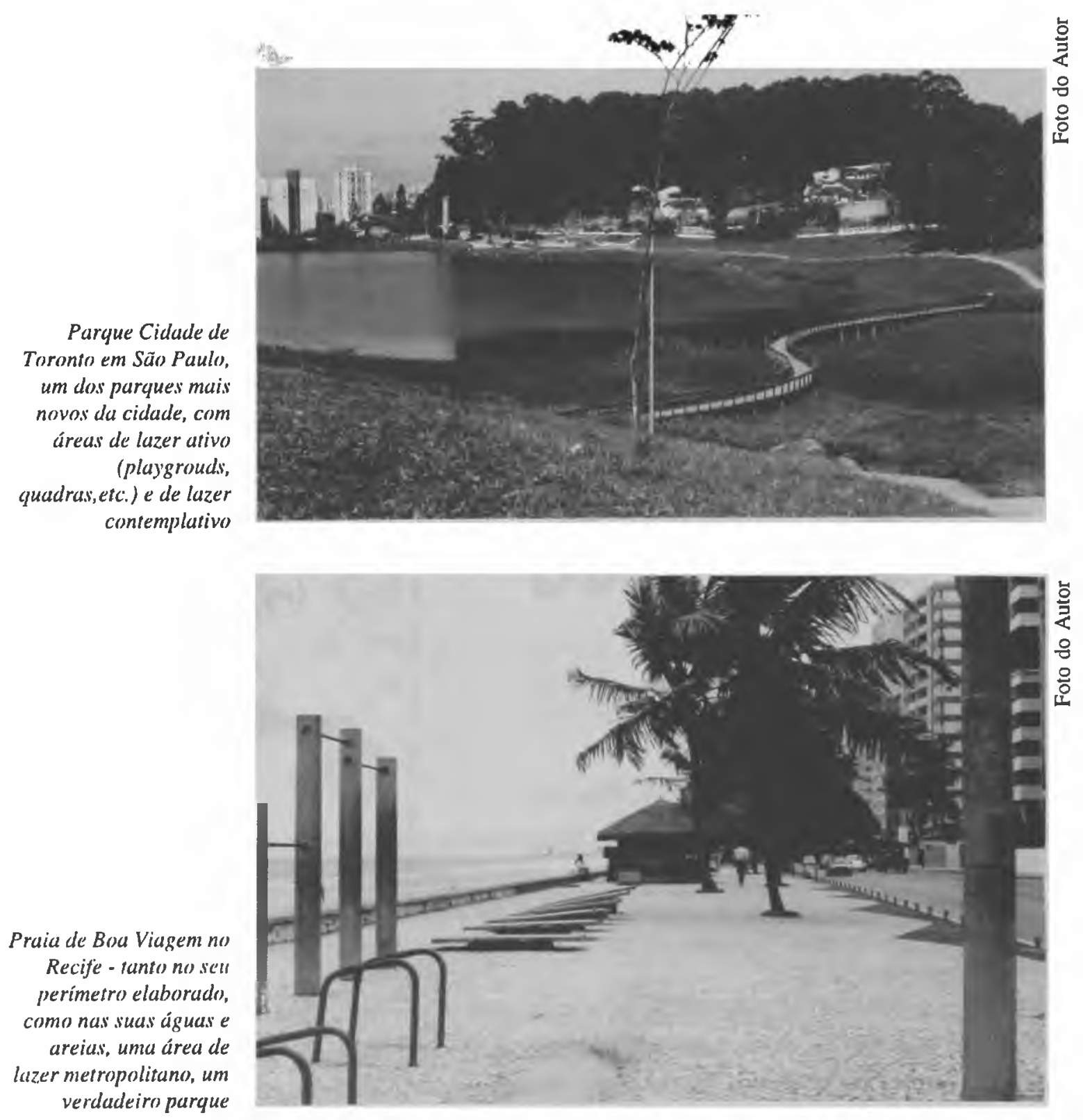


As praças rotatórias e equivalentes não podem ser incluídas em tal categoria, já que não permitem uma real propriacãd)e estadia do usuário em seu interior. Paralelamente terrenos vazios, como omcontrados nas várzeas de rios que cruzam as cidades e são utilizados freqüentemente pela população para jogos e brincadeiras, podem ser considerados como áreas de lazer, pelo menos enquanto se mantém tal tipo de uso "alternativo"

A sua existência explica de tal forma o baixo grau de exigência de moradores de pequenas e médias cidades, por áreas de lazer, pois este é praticado realmente em tais áreas ou nas terras vizinhas aos seus perímetros urbanos, onde são comuns os piqueniques, caminhadas e jogos junto a cachoeiras, lagos e riachos.

A cidade de Santa Rita do Jacutinga no sul do estado de Minas Gerais é um bom exemplo deste fato. Possui apenas três pequenas praças, mas está cercada por incontáveis recantos aprazíveis como cachoeiras e rios, onde a população costuma dispender muitos de seus momentos de ócio.

ÁREA DE CIRCULACÃO-Dentro do contexto urbano. englobam a grande maioria dos espaços livres de edificacão de propriedade pública (no caso todo g(sistema viário) e parte do sistema privado de espaços, tais como vilas e sistema viário de condomínios.

Formalmente se destinam exclusivamente à circulaçãn eacesso de veículos e pedestres, tendo durante todo o século 20, sido especialmente desenvolvidas técnicas de projeto e desenho para tais espaços. A foto da rua Maranhão (no bairro de Higienópolis em São Paulo), datada do início do século, mostra uma configuração onde as árvores estão colocadas ao largo dos passeios de pedestres em meio ao leito carroçável (talvez se amarrassem cavalos nos seus troncos?).

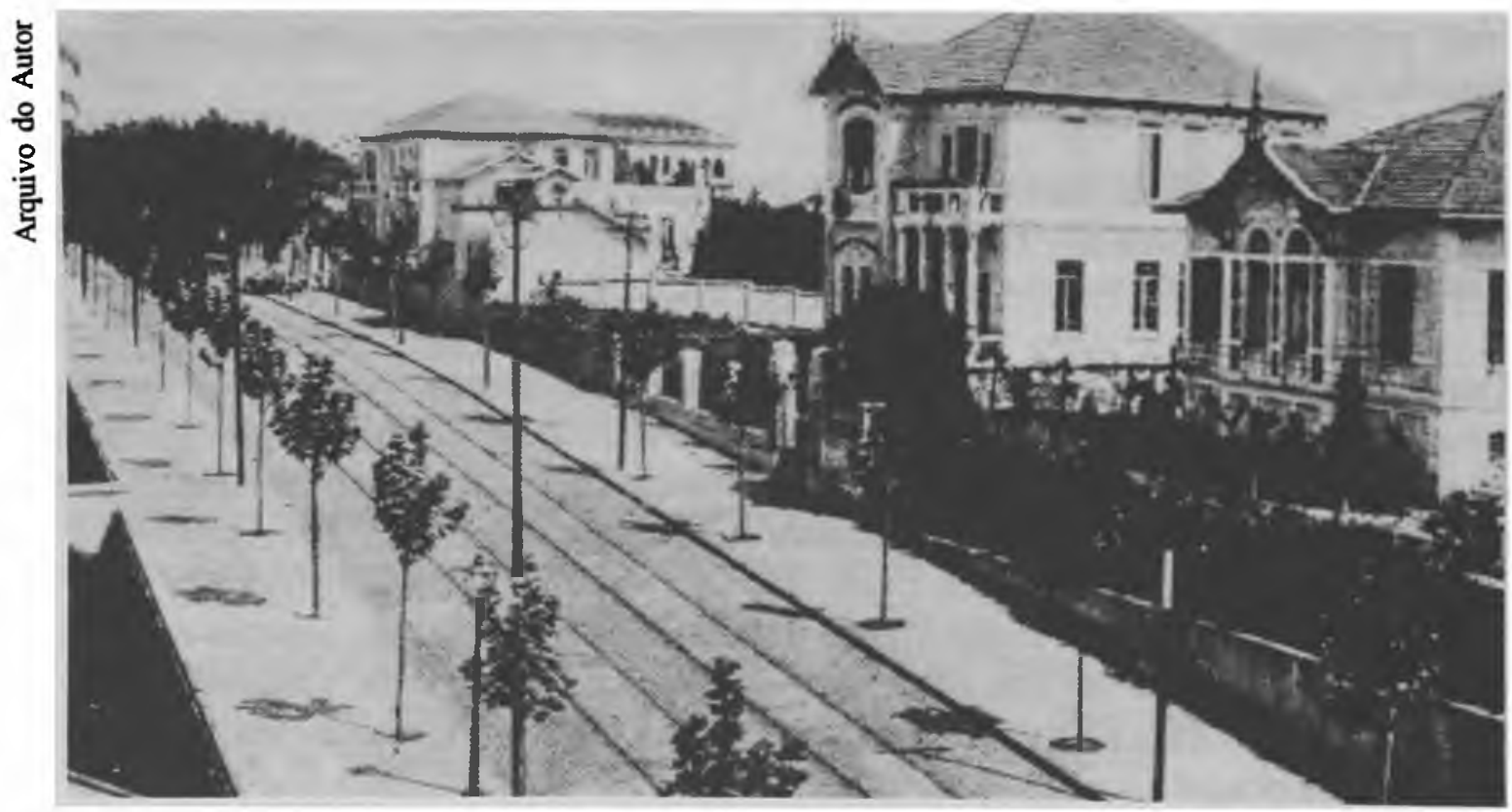


A foto da mesma rua nos anos 70 nos mostra uma estruturação clara e típica de qualquer rua de uma cidade contemporânea, onde os caminhos do pedestre e o do veículo estão determinados e a arborização está definitivamente contida dentro dos limites das calçadas.

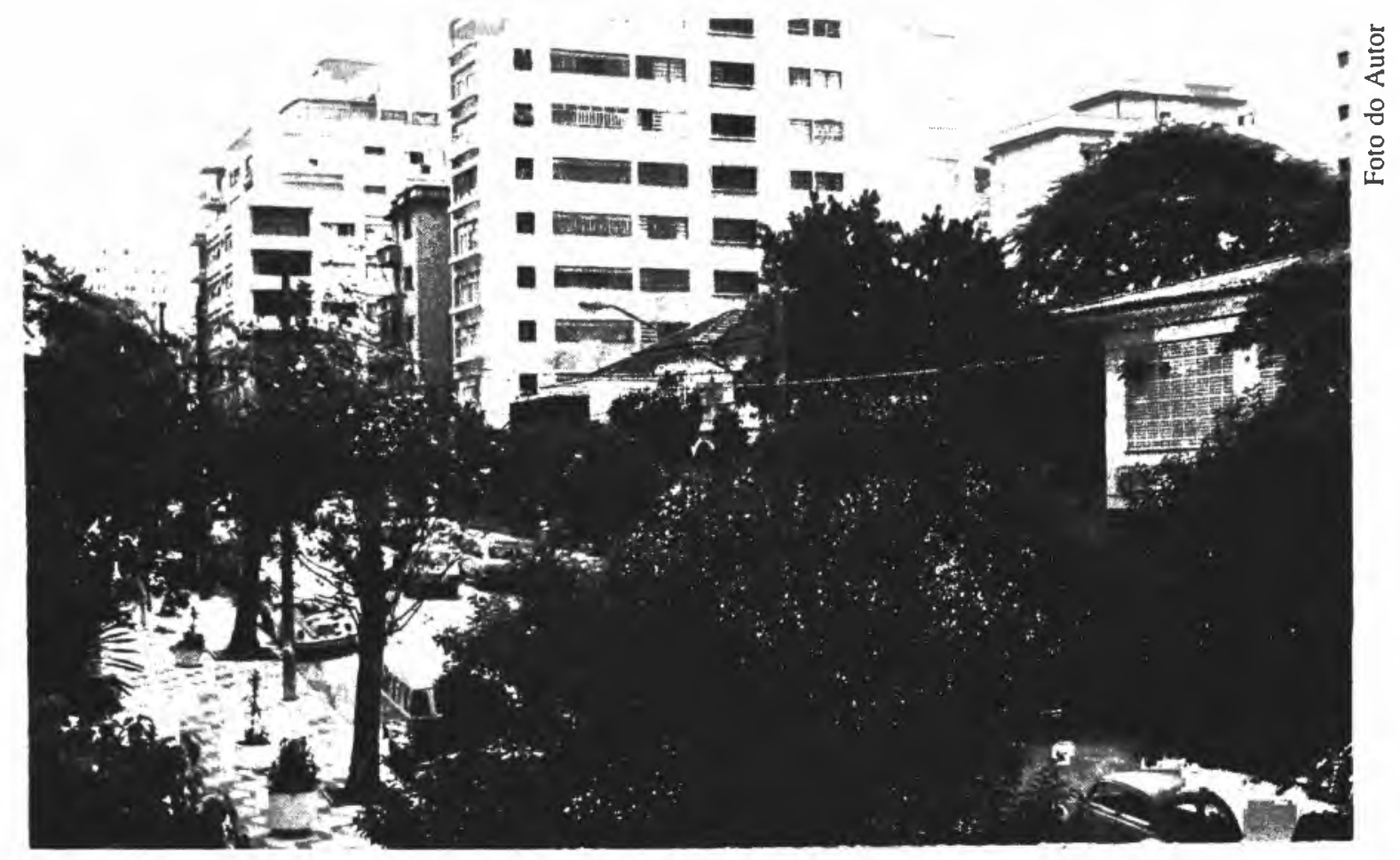

Como os terrenos baldios, várzeas, etc., as ruas assumem na cidade brasileira um papel complementar, servindo de espaço de lazer para a população, que desde tempos imemoráveis, utiliza-a para suas conversas e jogos. Na cidade moderna. com o aumento do tráfego nas áreas centrais, praticamente desaparecem tais atividades, que permanecem, entretanto, nas tranquiilas ruas dos subúrbios de bairros residenciais de baixa densidade.

A paisagista Ayako Nishikawa, ao final da década de 70, organizou uma pesquisa sobre o tema ruas de lazer em São Paulo e detectou uma infinidade de usos para tais espaços ${ }^{6}$ que estão explicitados no quadro a seguir.

Tanto nestas ruas, que no caso eram destinadas especialmente ao lazer nos fins de semana, quando tinham seus espaços fechados ao trânsito de veículos, como em toda e qualquer rua tranqüila, observa-se freqüentemente o uso do leito carroçável para todos estes fins, principalmente os jogos de crianças e adolescentes.

A multiplicidade de usos é muito grande e tais atividades se dão em espaços que não foram projetados para tal fim. Estes são, por muitas vezes, mais variados que os encontrados em espaços especialmente destinados a jogos e à recreação como setores de parques e praças. 


\begin{tabular}{|l|}
\hline LAZER DE FIM DE SEMANA \\
\hline NOS ESPAÇOS LIVRES: \\
\hline Brincar \\
\hline Jogar bola \\
\hline Caminhada (perto) \\
\hline Conversar/Encontros \\
\hline Passeio (distante) \\
\hline Parque/Praça/Horto, etc. \\
\hline
\end{tabular}

\begin{tabular}{|l|}
\hline LAZER COTIDIANO \\
\hline NOS ESPAÇOS LIVRES: \\
\hline Brincar (em qq/lugar) \\
\hline Brincar na rua ou praça \\
\hline Jogar bola \\
\hline Passeio (caminhada) \\
\hline Ir a praça \\
\hline Conversa/Encontro \\
\hline
\end{tabular}

\begin{tabular}{|l|}
\hline OUTROS LOCAIS (E EM CASA) \\
\hline Jogo (ping-pong, carta, etc.) \\
\hline Visitas \\
\hline Festas \\
\hline Escola de samba \\
\hline Piscina/Andar a cavalo \\
\hline Centro Esportivo \\
\hline Andar de moto \\
\hline Pesca \\
\hline Sítio \\
\hline
\end{tabular}

\begin{tabular}{|l|}
\hline OUTROS LOCAIS (E EM CASA) \\
\hline Jogo (cartas, dominó, etc.) \\
\hline Visitas \\
\hline Centro Esportivo/Escola \\
\hline Natação/Judô/Futebol \\
\hline
\end{tabular}

As ruas podem se constituir, e se constituem na maioria dos casos. em espacos de lazer, possibilitando encontros informais, jogos e até algumas atividades de trabalho. como a lavagem e o conserto de veículos. e, como tal devem ser consideradas em todo e qualquer planejamento de áreas de lazer?

Vilas, vielas e ruas com acesso restrito de veículos têm se mostrado os espaços mais adequados para o lazer, pois oferecem condições quase que ideais ao seu usuário, deviđo ao tráfego escasso ou controlado (caso das vilas e vielas), oferecendo como vantagem adicional a possibilidade de uma diversidade de usos.

Esta diversidade é favorecida pela constituicão formal destes espaços pisos simples, pavimentados que por este mesmo motivo se adaptam às mais diversas situaçoes, do jogo de bola, ao pular corda e a roda. 


\section{QUALIFICAÇÃO}

A duração - vida útil - de um determinado espaço livre urbano pelo tempo afora, está diretamente vinculada à possibilidade constante de apropriacão que este permite ao seu público usuário. Ouanto mais e melhor possa ser apropriado, desde que convenientemente mantido, maior vai ser sua aceitação social e por mais tempo será mantida sua identidade morfológica. 米

Espaços como a praça de São Pedro (Roma), que atravessa séculos com a mesma configuração morfológica, são bons exemplos desta afirmação. Mesmo na cidade de São Paulo, pode-se encontrar um número significativo de espaços nestas condições, tanto logradouros públicos, como a praça da República, ou espaços semipúblicos, como vilas e vielas.

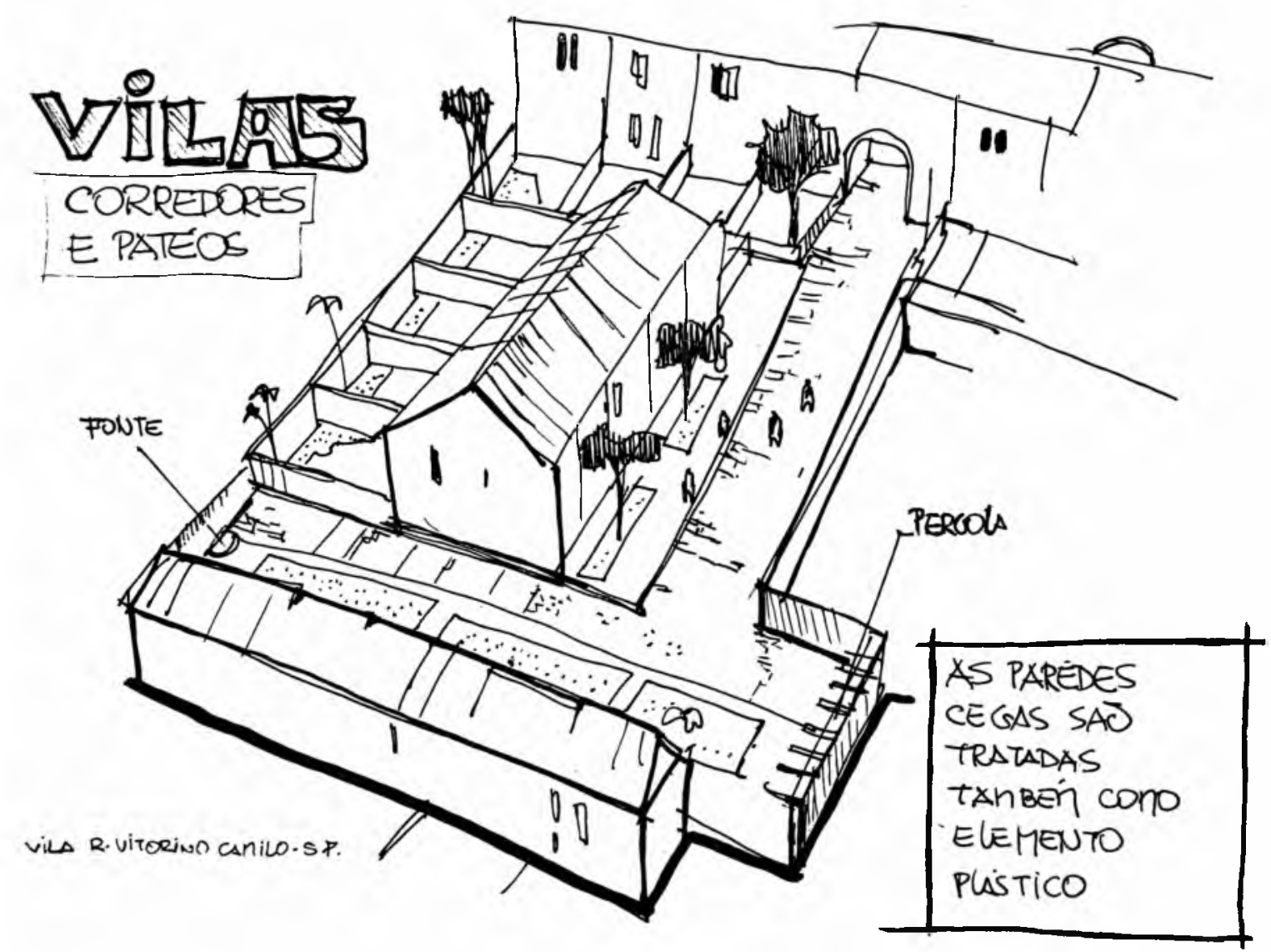

Se a possibilidade de diversidades de uso qualifica em termos de obsolescência durabilidade/estabilidade um espaço livre de edificações ou de urbanização, três fatores devem ser sempre considerados na avaliação de qualquer espaco livre:

1. Adequação funcionail- a correta conformação morfológica e dimensional, que permite sua utilização para esta ou aquela finalidade.

2. Adequação ambiental que permite ao seu usuário condições de salubridade, para o 
desempenho das mais diversas atividades. No caso, por exemplo, de um espaço urbano para recreação infantil em uma cidade de clima temperado, como as do sul do país, uma das condições seria o sombreamento moderado em dias de verão e a insolação plena em dias de inverno. No caso de uma mesma área em uma região tropical, a recomendação seria um sombreamento moderado durante todo o ano e assim por diante.

\section{EX:}

Muitos são os fatores, além do acesso à insolação que devem ser considerados. No caso, a ventilaçã adequada, qualidade e permeabilidade de sole e subsolo, estabilidade e rugosidades de pisos, declividades, graus de umidade, são pontos a serem considerados como tal.

3. Adequação estética a mais difícil de se avaliar, pois tais padrões variam constantemente de acordocom as mais diferentes expectativas sociais. Apesar desta dificuldade, este fator se mostra tão importante como os demais, pois a aceitação social-formal deste ou aquele espaço depende, em muito, dos citados padrões.

O exemplo gráfico nos mostra a estrutura morfológica de uma vila, situada na rua Piauí, no bairro de Higienópolis (próximo da área central), que nos seus 70 anos vida, manteve o seu arcabouço intacto, adaptando-se aos novos usos, apenas com pequenos arranjos dos seus subespaços.

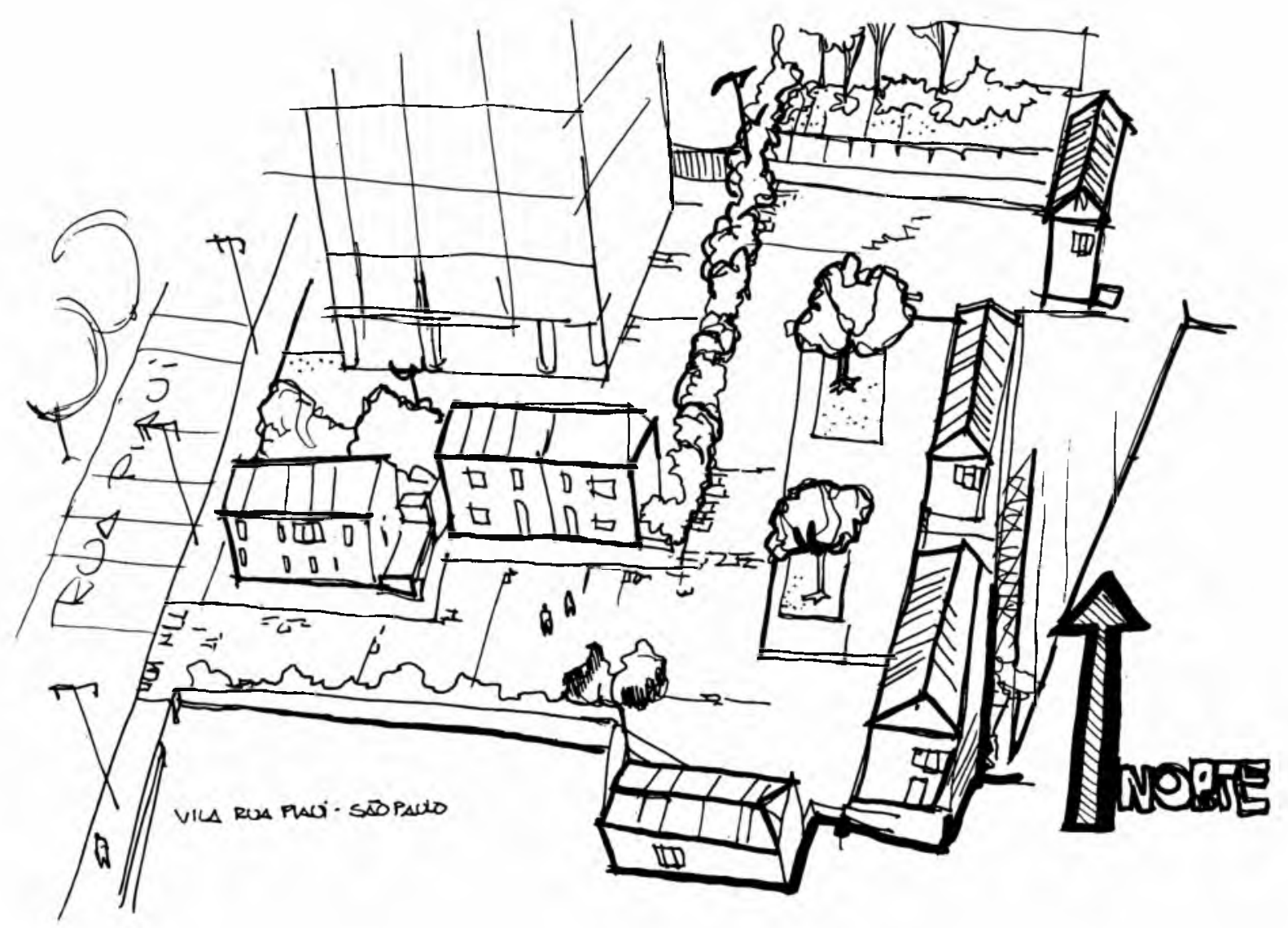


A vila do exemplo anterior, construída nos anos 20 , é ainda hoje considerada em termos estético um ótimo espaço urbano, pela sua configuração formal - um espaço determinado por construções "art deco" e todo ajardinado, estando plenamente adequado em termos dimensionais para suas funções ${ }^{8}$. Paralelamente, apresenta condições ambientais muito desfavoráveis, pois o conjunto está cercado por altos prédios e praticamente não recebe sol no inverno, apresentando no seu interior temperaturas inferiores aos espaços vizinhos (e este fato não a desmerece em termos estéticos!).

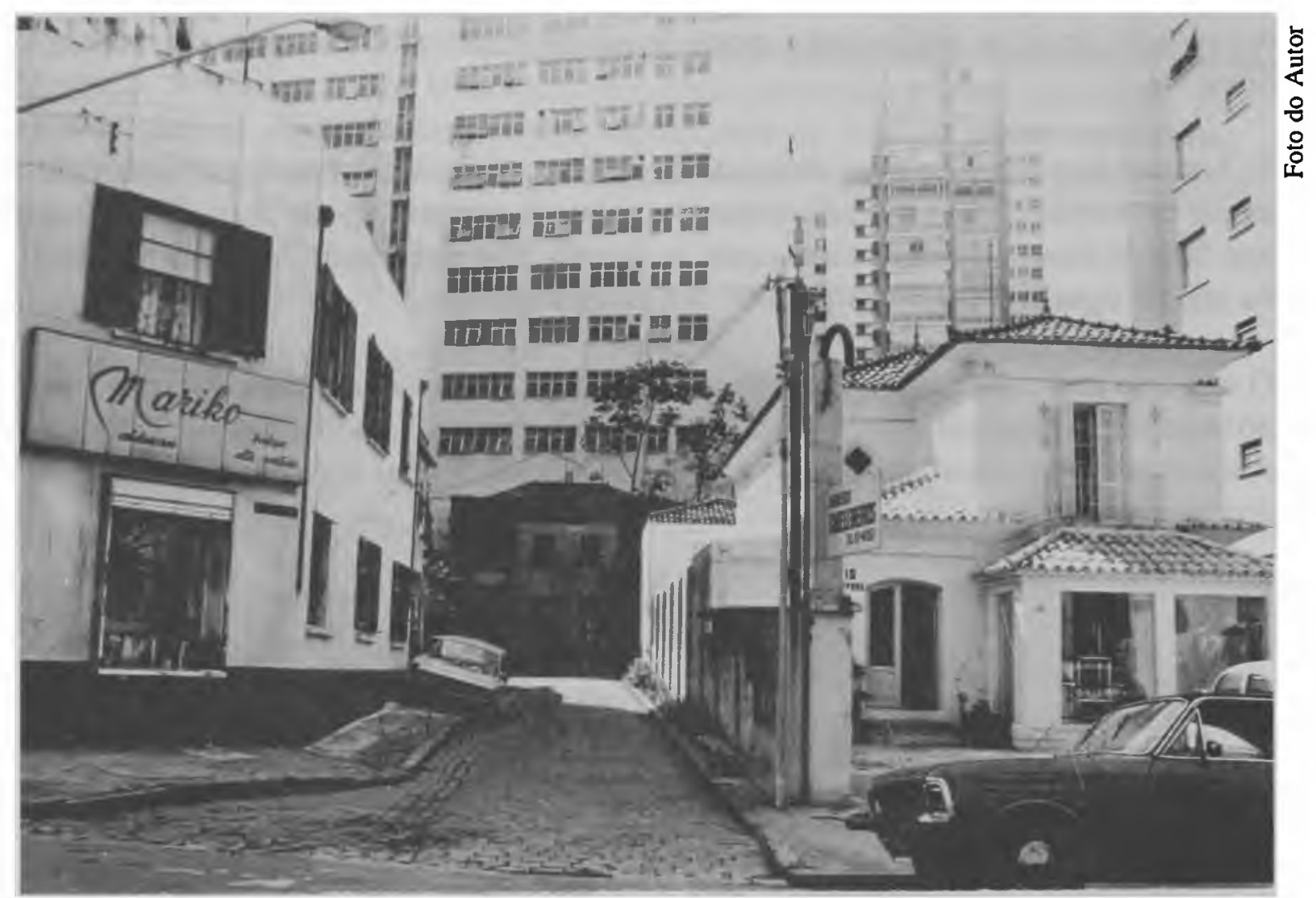

Vila em Higienópolis, São Paulo, totalmente cercada por altos prédios, apresenta sensíveis desiniveis de temperatura em relação ao seu entorno, pois não é iluminada por luz natural no inverno, devido a alta massa edificada existente

As mudanças de valor estético, tanto em nível do parcelamento quanto da estrutura tridimensional, são constatadas com facilidade ao observarmos os padrões de organização das praças públicas. Estas, até o início dos anos 40 , eram usualmente parceladas em canteiros ordenados em uma retícula ou formados por curvas sinuosas ${ }^{y}$. Estas formas de organização foram substituídas por outras, pelo menos naqueles espaços que se pode considerar como projetados dentro de cânones modernos ou contemporâneos. Estas privilegiam formas mais geometrizadas, suprimem motivos pitorescos, como fontes e esculturas neoclássicas e incorporam em sua configuração, por exemplo, os equipamentos esportivos (em praças de bairro principalmente) e a idéia do plantio quase que exclusivo de vegetação nativa. Deve lembrar, no caso, que durante toda a "belle époque" era padrão nos jardins das famílias da época, o ajardinamento de influência européia, com a utilização de plantas importadas como boxo, plátanos, etc. 


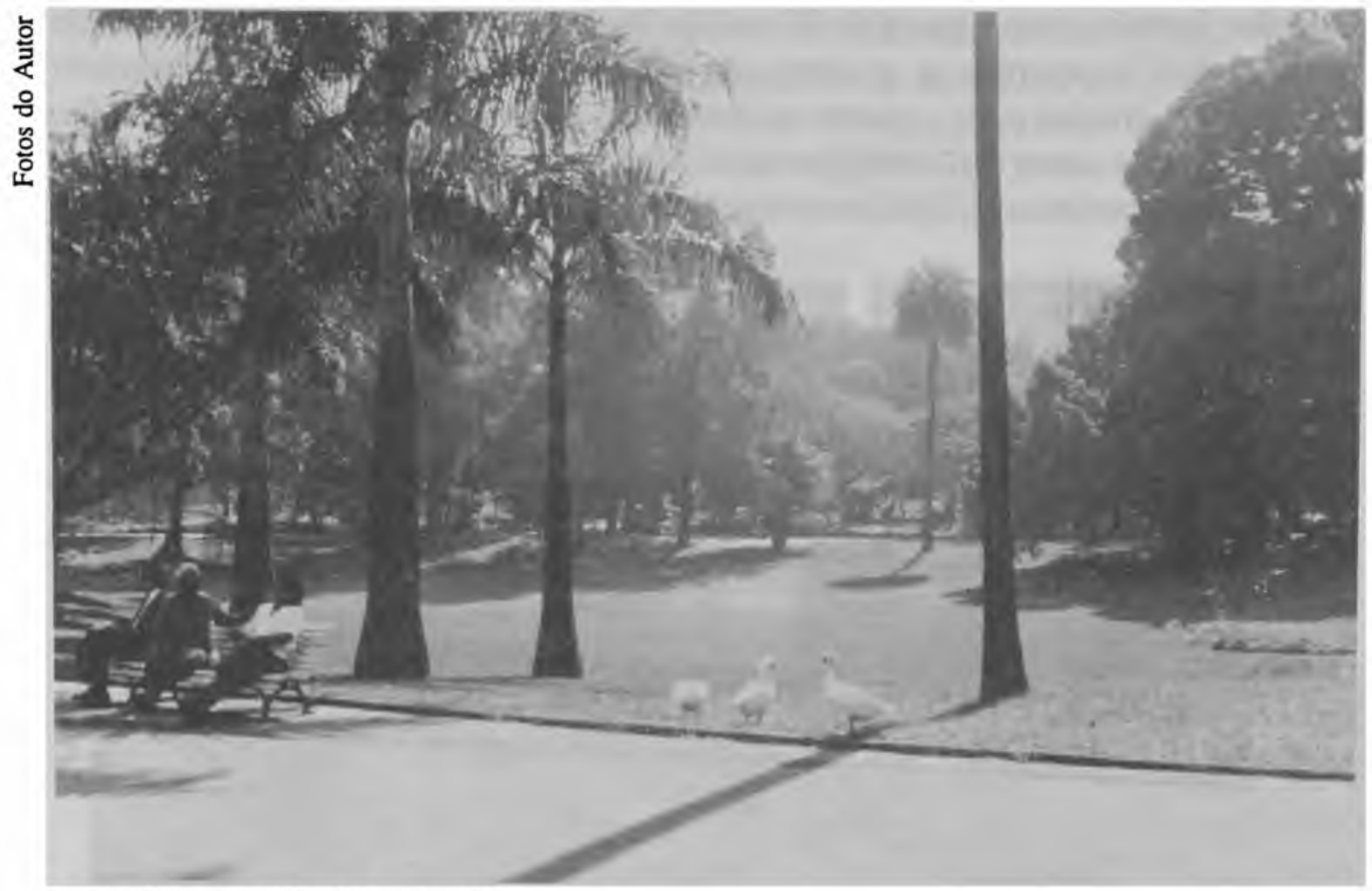

Campo de Santana - Rio de Janeiro - RJ

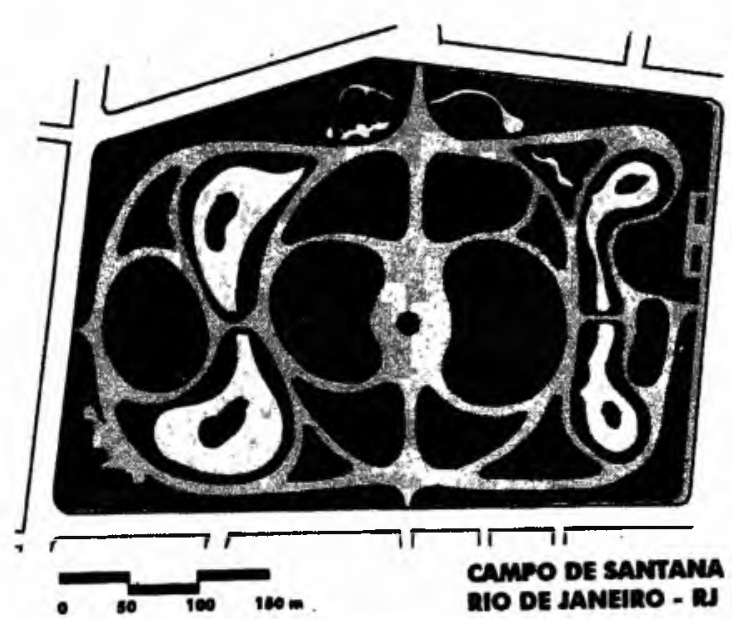

Campo de Santana - Rio de Janeiro - RJ

Praça da Sé - São Paulo - SP

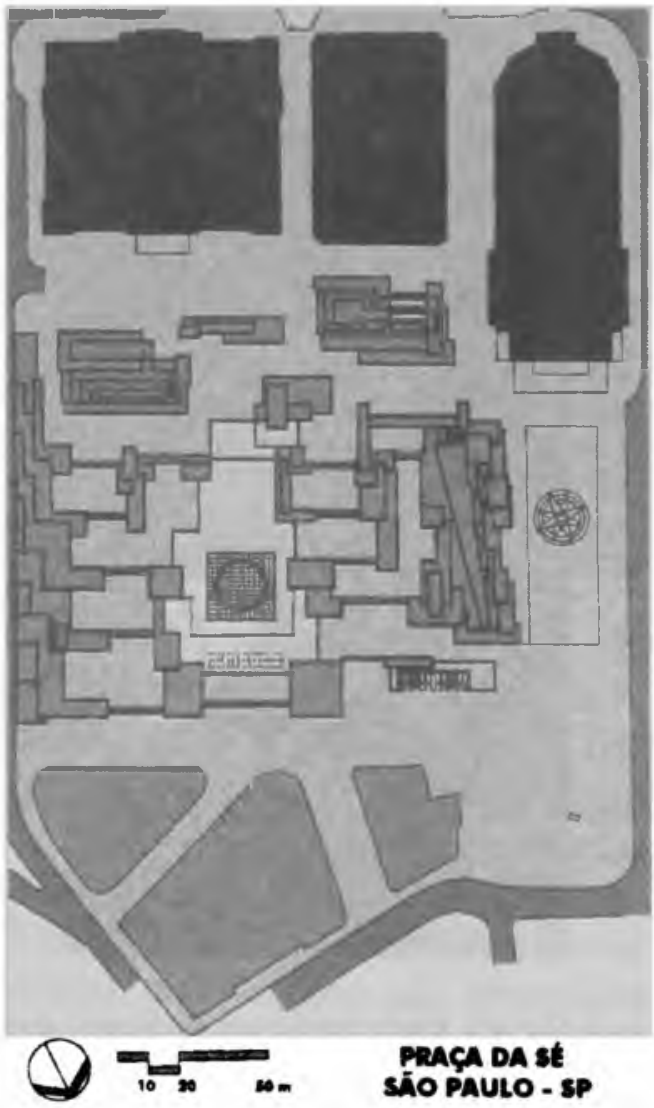

Paisagem Ambiente Ensaios São Paulo n. 7 p. 15 - 56 jun. 1995 


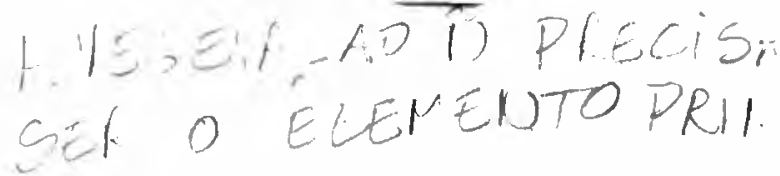

Situações formais como a praça da Sé em São Paulo, ou o largo da Carioca no Rio de Janeiro seriam impossíveis de existirem até poucos anos atrás, pois o autor do projeto privilegiou os grandes pisos e planos em detrimento de um ajardinamento. A vegetação, no caso, aparece como um elemento secundário, compondo alguns planos verticais $\mathrm{e}$ tendo sua característica decorativa colocada de um modo secundário.
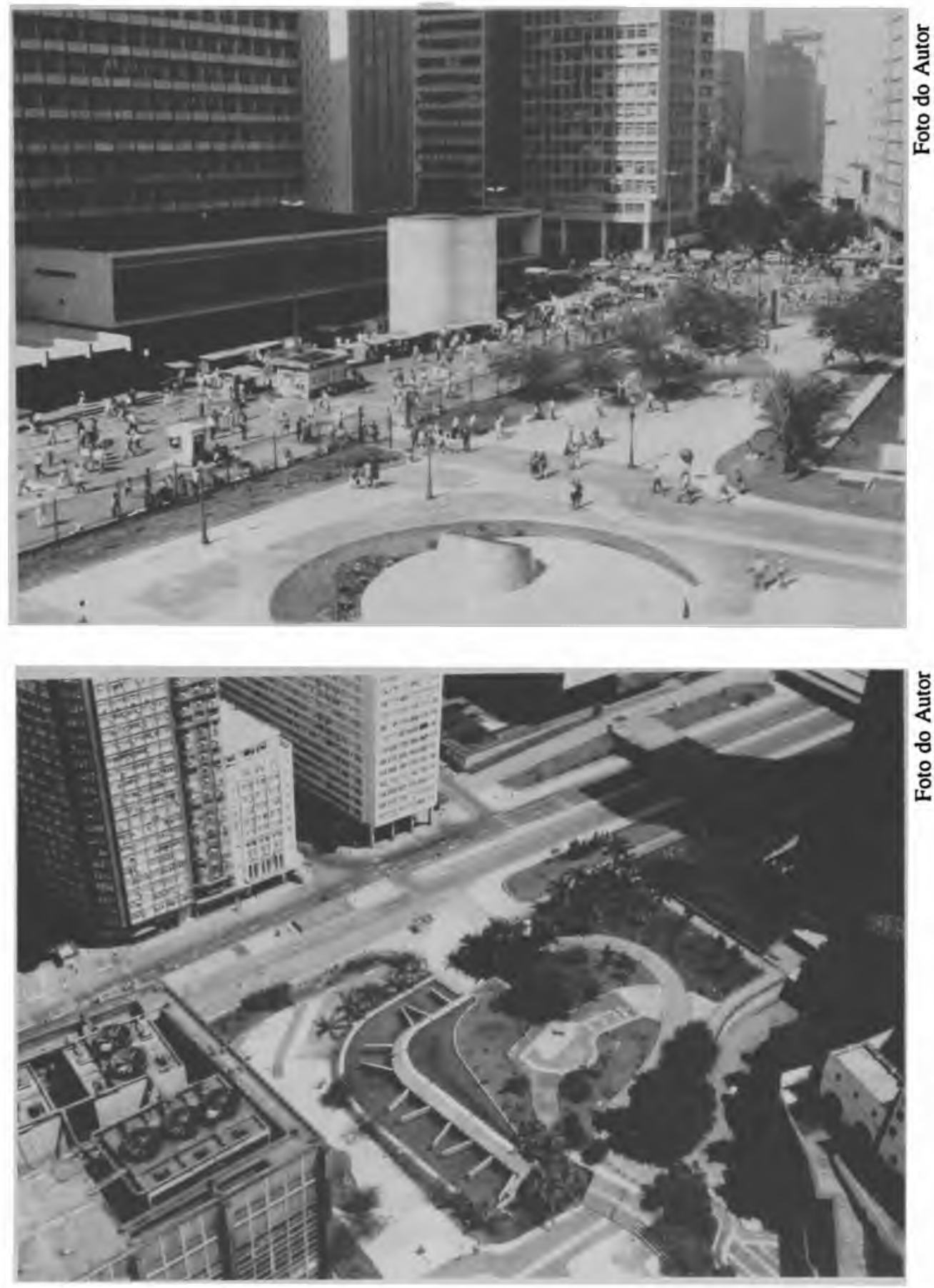

Largo da Carioca, Rio de Janeiro, um dos projetos mais requintados de Burle Marx, ao mesmo tempo em que apresenta apenas um grande piso de mosaico português em desenhos, apresenta uma grande qualidade cênica e uma diversidade de possibilidades de uso 
Esta mudança do tratamento dos espaços livres de edificação se dá no Brasil, em especial a partir dos anos 50. quando os vellhos padrões de projeto são abandonados pelos principais arquitetos paisagistas do país. Esta foi uma década de intensa afirmação nacional e a consolidação da figura de Roberto Burle Marx xomo o paisagista oficial brasileiro faz com que um novo paradigma projetual seja adotado, criando-se então um outro padrão estético para o paisagismo brasileiro.

Apesar da obra de Burle Marx ser expressiva e já vir influenciando o paisagismo nacional desde o seu projeto para as praças de Recife e para o Ministério da Educação e Cultura no Rio de Janeiro, foi nesta década e na posterior (de 60), que este se afirma com obras de vulto no mesmo Rio de Janeiro - Aterro do Flamengo, e em Brasília, a nova capital ${ }^{10}$.

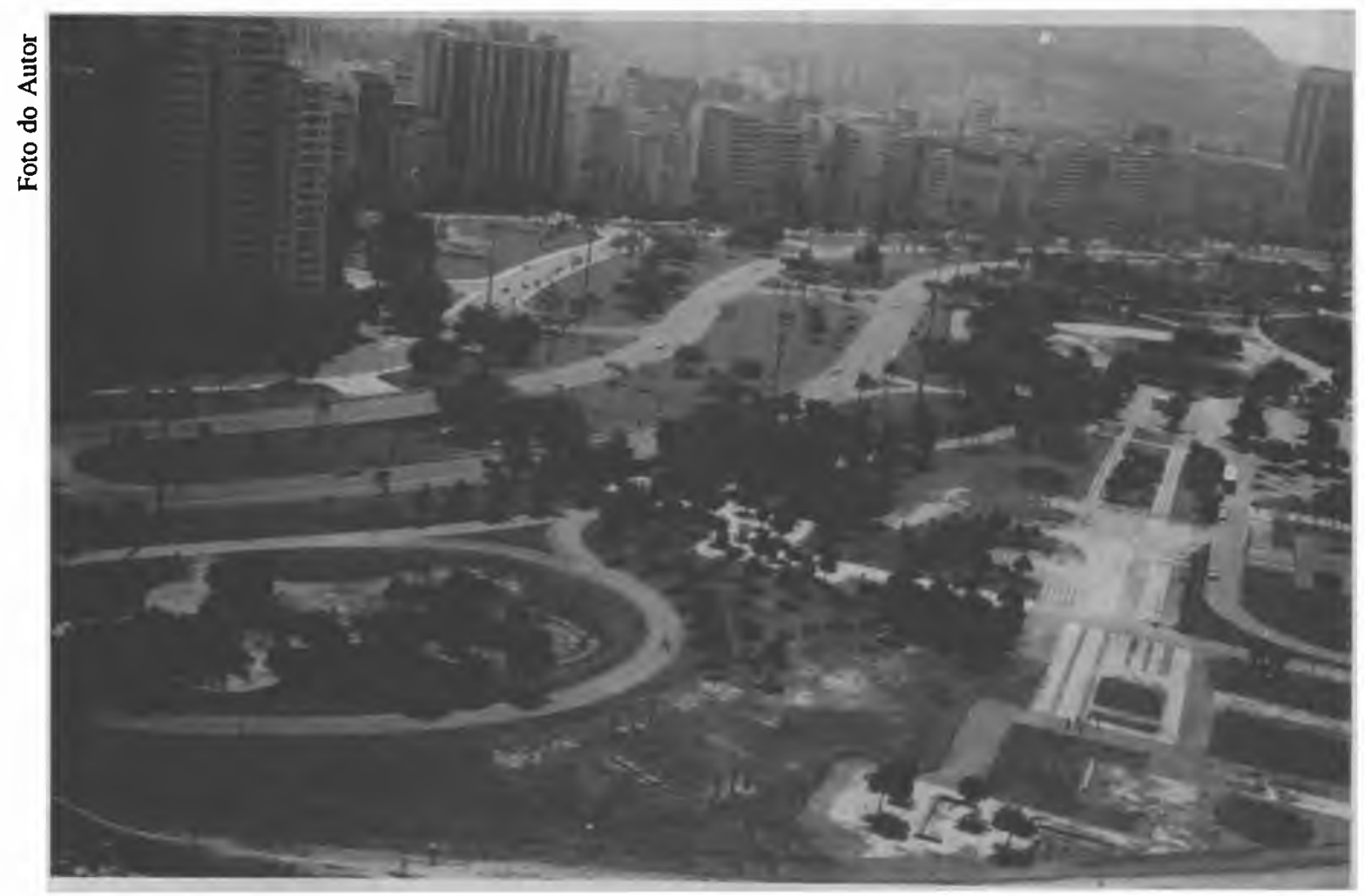

Vista aéréa do Aterro do Flamengo, Rio de Janeiro

Outros padrões estéticos inspirados em formas muito geométricas e conceitos espaciais diferenciados são incorporados na obra dos paisagistas nacionais principalmente inspirados nos projetos e conceitos paisagistas americanos da Costa Leste Americana (Halprin, Eckbo e outros mais). Novas formas e desenhos são utilizados a princípio pelos paisagistas paulistas, irradiando-se por todo o país ${ }^{11}$. Sob sua égide são desenvolvidos calçadões, jardins, praças e parques nas grandes cidades, que são posteriormente reproduzidos de um modo bastante adulterado e misturado às velhas tradições, nas pequenas cidades do interior brasileiro ${ }^{12}$ 
米

\section{HELPRII) ou ECKBO}

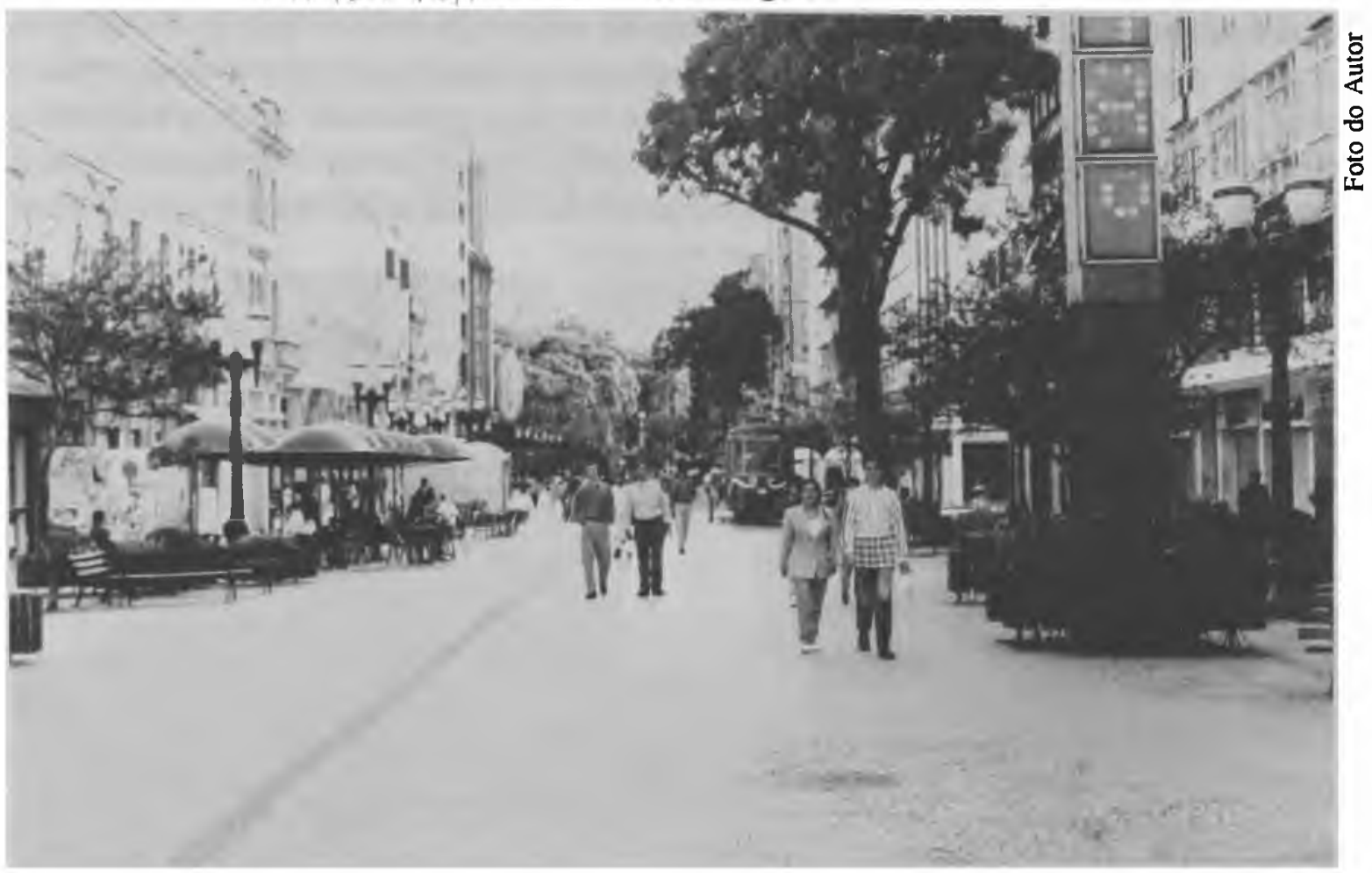

Curitiba, calçadão da Rua 15 de Novembro: este espafo, pioneiro com este tipo de tratamento no Brasil, sofre uma grande influência das duas correntes paisagisticas

No final do século, na década de 90 se observa uma consolidação das duas linhas projetuais que, fundidas ou não, definem os padrões morfológicos nara os espacos livres de edificacão ditos contemporâneos. As solucões do ecletismonão estão apagadas do imaginário popular e persistem, tanto nos espaços construídos no início do século (e ainda intactos) como em novas propostas para o mercado imobiliário, direcionando 0 projeto de inúmeras obras, sejam jardins, pátios e até mesmo praças.

Não se pode nunca definir claramente um padrão estético adequado, mas identificar aquele que, por um motivo ou por outro, é o mais aceito pela sociedade.
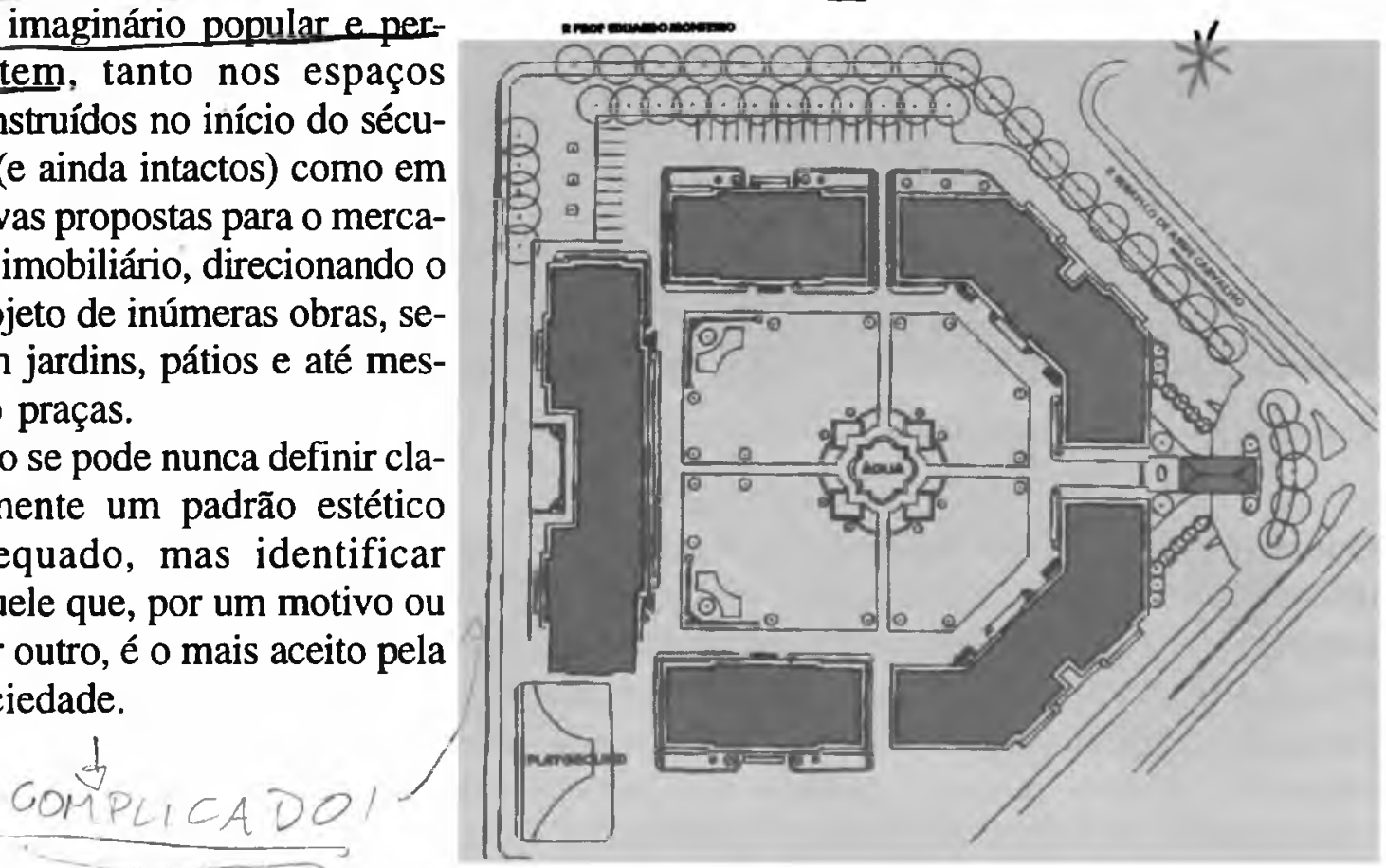

Place des voges 


\section{ESTRUTURA MORFOLÓGICA}

Do mesmo modo que os edifícios, os espaços livres podem ser definidos morfologicamente por planos verticais e horizontais (paredes ou vedos, pisos e tetos) No caso específico, os tetos sempre são os mesmos, transparentes e permeáveis - seriám as copas dos arvoredos- ou infinitos (o céu) e, nunca, telhados tradicionais.

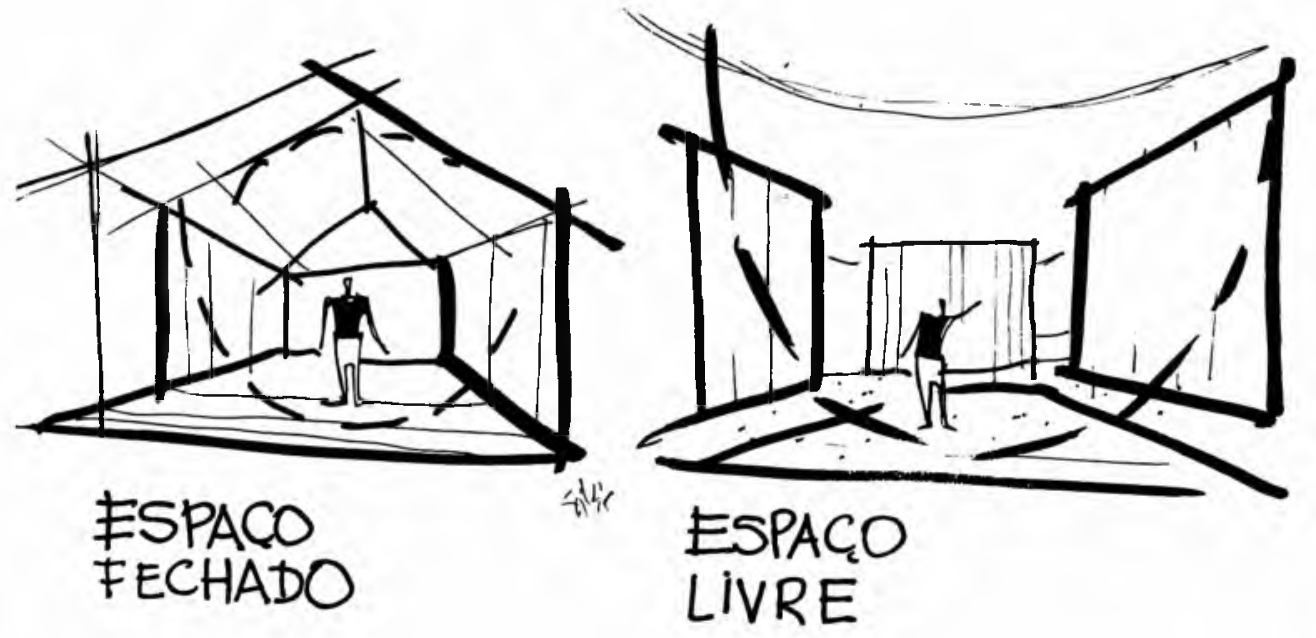

Os planos verticais são as construções, edifícios e muros, taludes, morros, arvoredos e maciços de arbustos, enquanto os planos horizontais paupáveis são sempre os pisos.

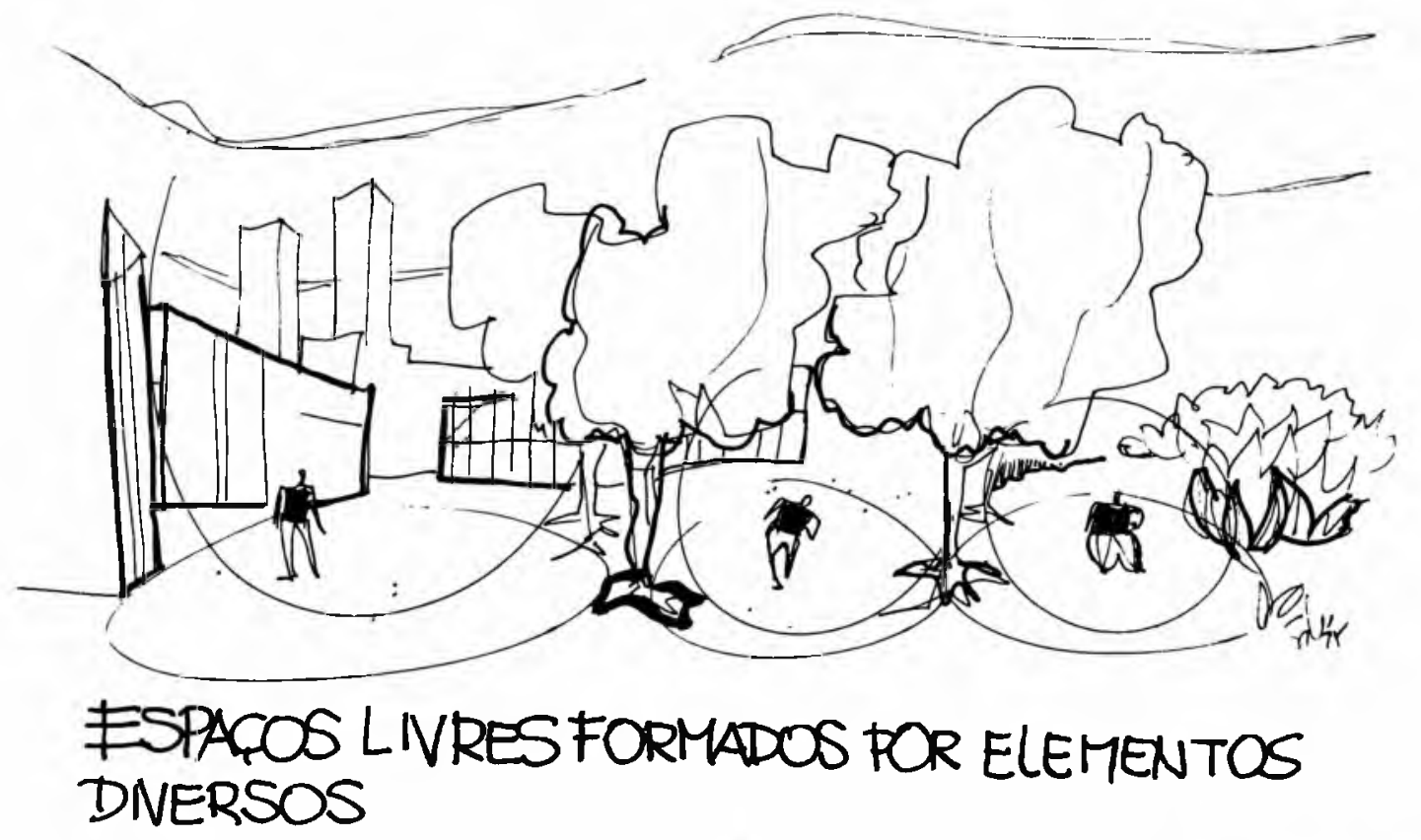

A vegetação nem sempre estrutura espacos. Dentro do contexto urbano somente em
alguns espaços, como os grandes parques, tanto públicos como privados, são estruturados
por vegetação. Os parques Farroupilha (Porto Alegre) ou Ibirapuera (São Paulo), são
bons exemplos deste fato, sendo totalmente definidos por vegetação. Fora do contexto 
urbano, a vegetação, juntamente com o suporte físico é o principal elemento definidor dos espaços e caracterizador de paisagens.

Parque Ibirapuera - Sāo Paulo - SP
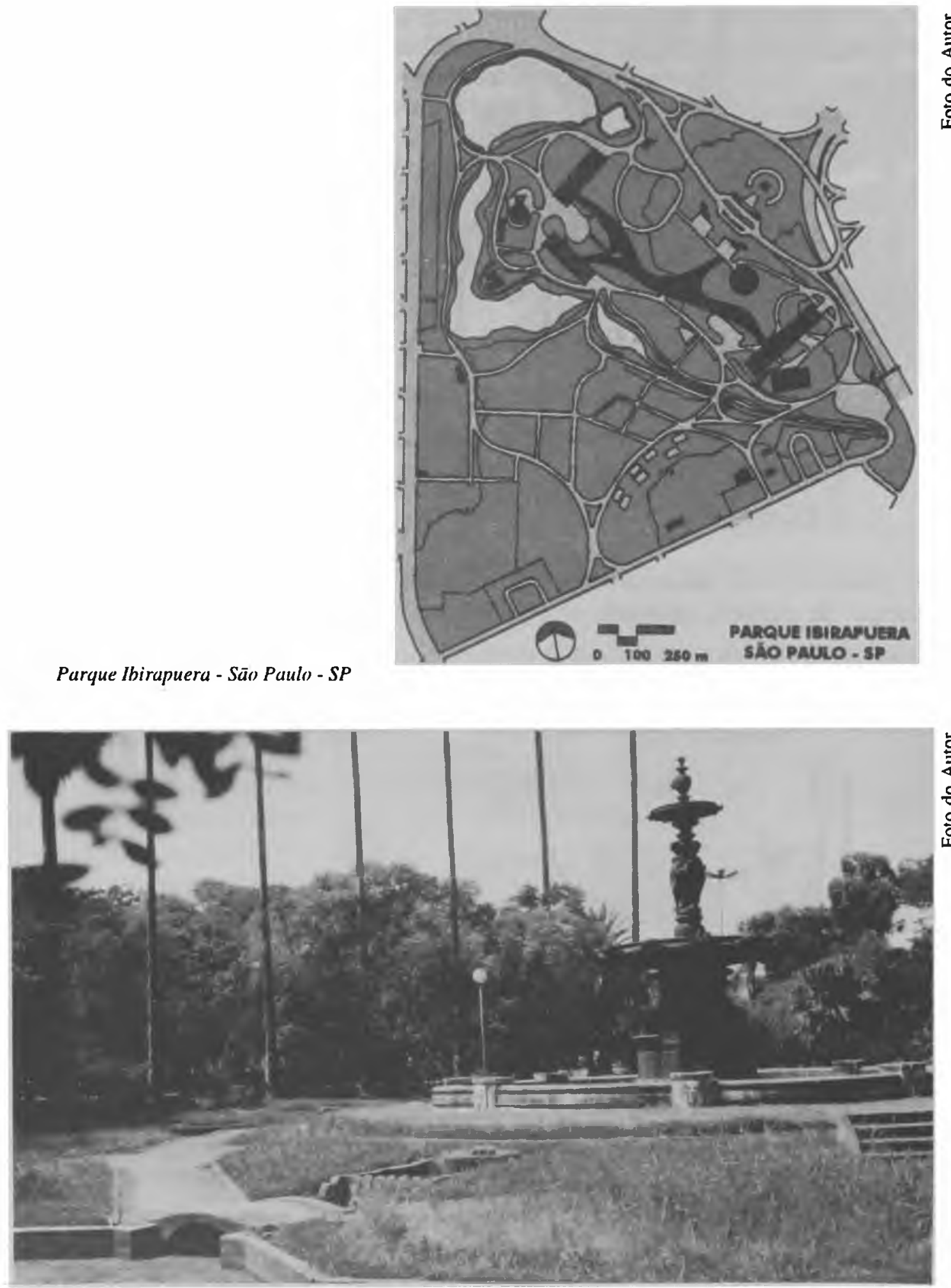

Parque Farroupilha on da Redençāo, Porto Alegre: é o parque mais tradicional da cidade, cuja estrutura morfológica é haseada na organização das massas de vegetaçäo 


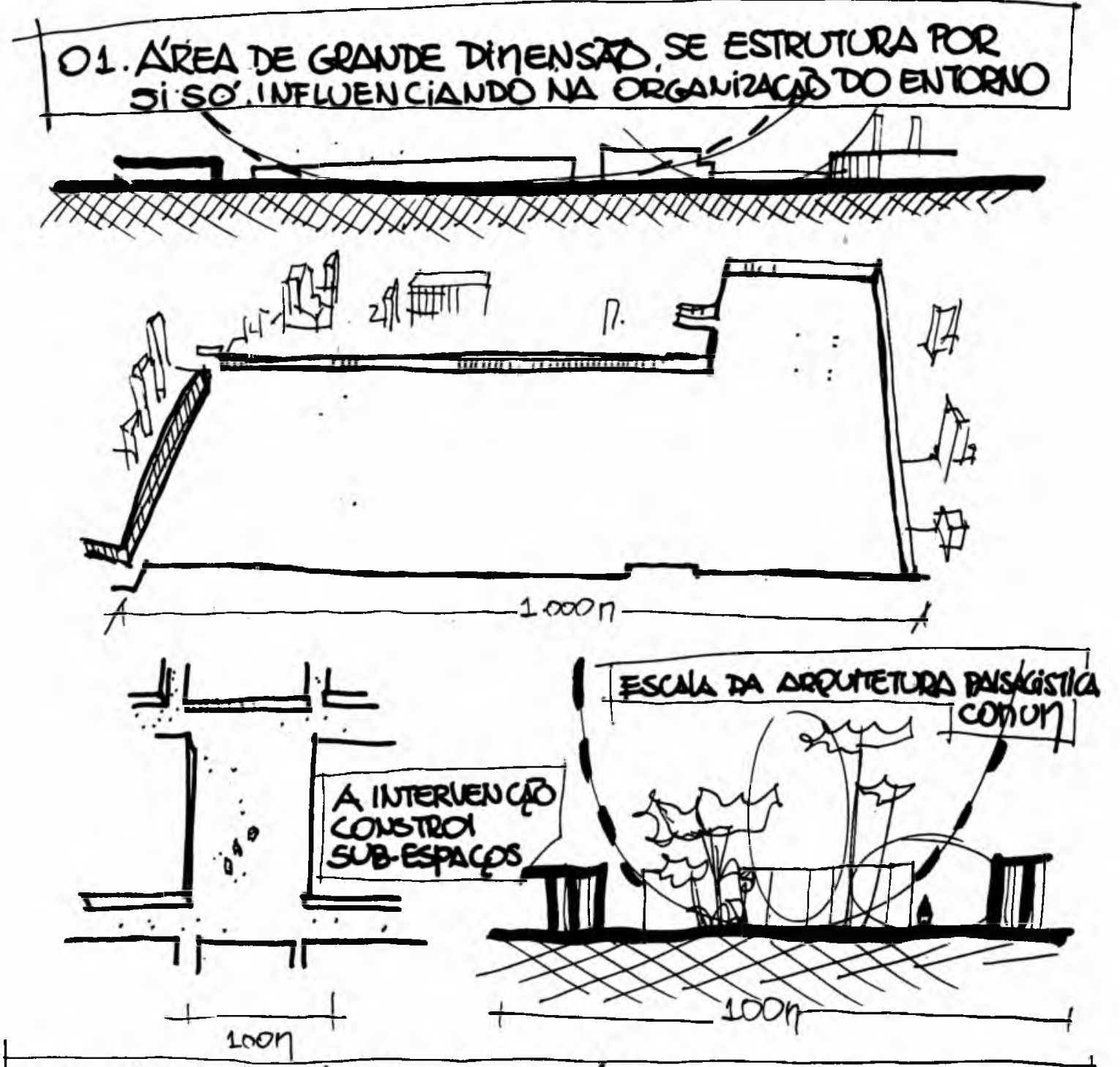

O2. ÁREAS DEFINIDAS MOREOĹGiCANENTE PElO ENTORNO
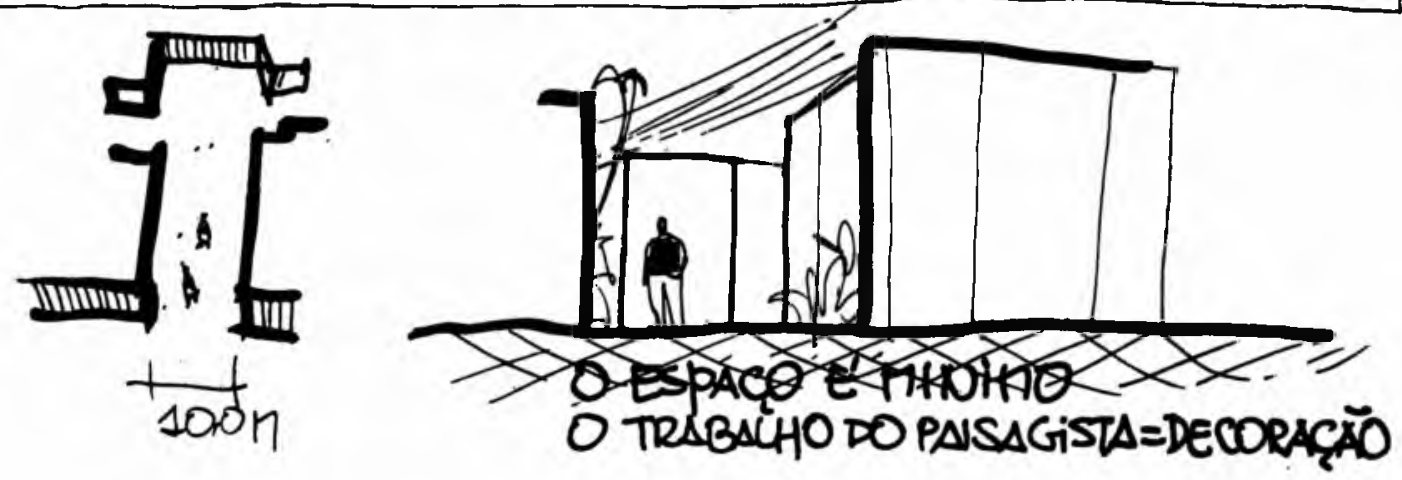
No caso das diversas praças o que se observa é que todas são definidas primeiramente pelo contexto construído do entorno e que a princípio independem da vegetação como elemento estruturador. Espaços como a praça da República em São Paulo, mesmo que definidos aparentemente pelos seus arvoredos, subsistiriam morfologicamente independentemente da existência de vegetação. $\mathrm{O}$ mesmo fato pode ser observado nas vias de circulação - ruas, vilas, avenidas, etc., que, independem de arvoredo para ter uma identidade morfológica própria.
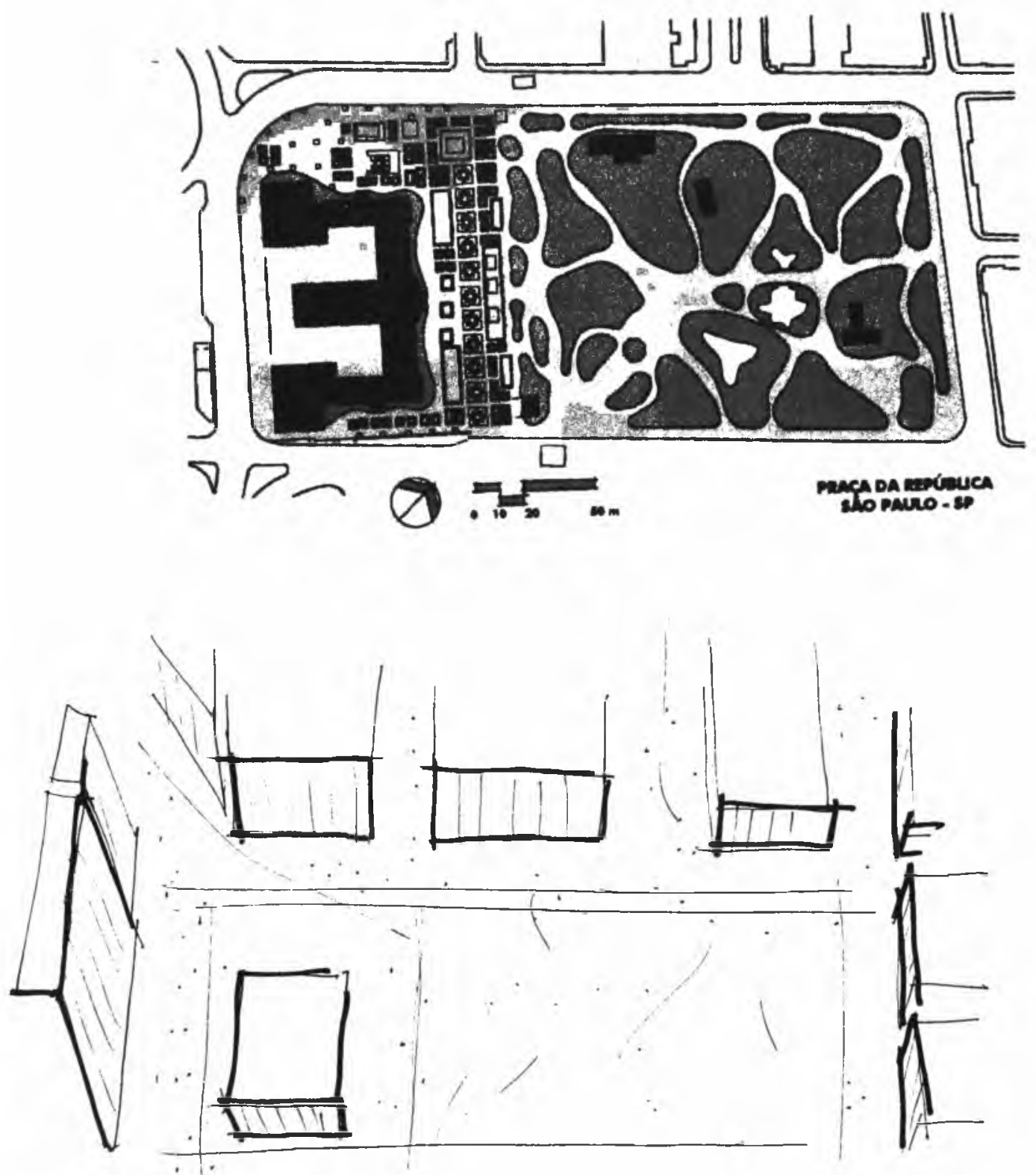

PRACA DA REPUBLICA - ESTRUTURA MORFOLÓGICA WEsPACOS LIURES 
A existência deste planos horizontais e verticais e a sua utilização como referência construtiva de espaços livres é muito importante e não claramente perceptível pelo leigo. Este geralmente associa os espaços livres à idéia de uma entidade fluida não mensurável. Diversos autores têm elaborado trabalhos, que nos direcionam para sua percepção (Lynch, Ashihara, Cullen e outros) e para sua avaliação (Hillier e seus seguidores nacionais, Benamy Turkienicz, Frederico Holanda e outros) ${ }^{13}$. Estas teorias e conceitos têm sido muito estudados dentro do meio acadêmico e pouco aplicados no cotidiano do projeto urbano na geração de novos espaços livres de edificação públicos ou privados.

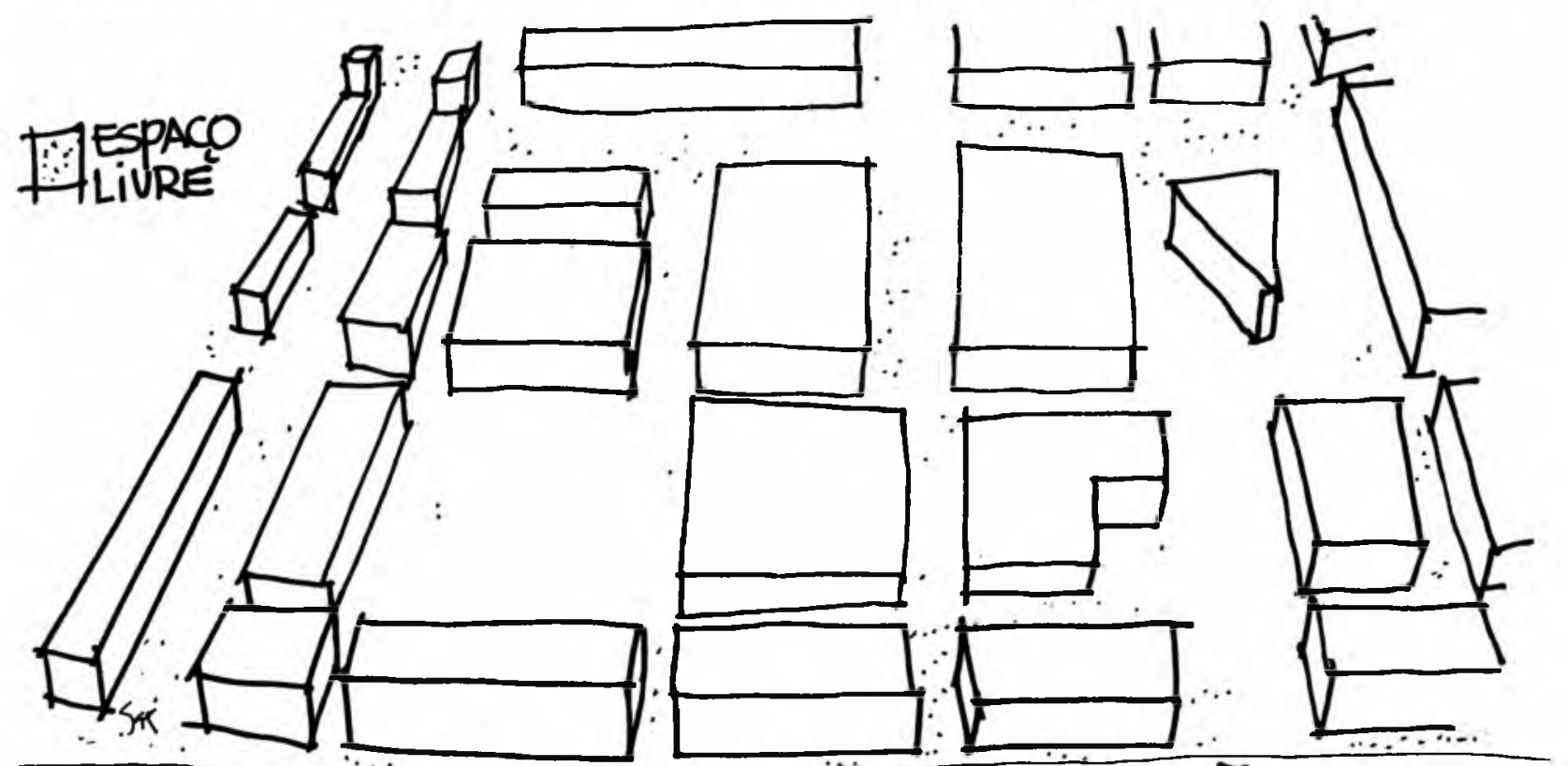

\section{A PAISAGETI DETERTIINADA PELA ASSOCLACCAOO DE VOLUTES CONSTRUIDOS E ESPACQS LIVRES.}

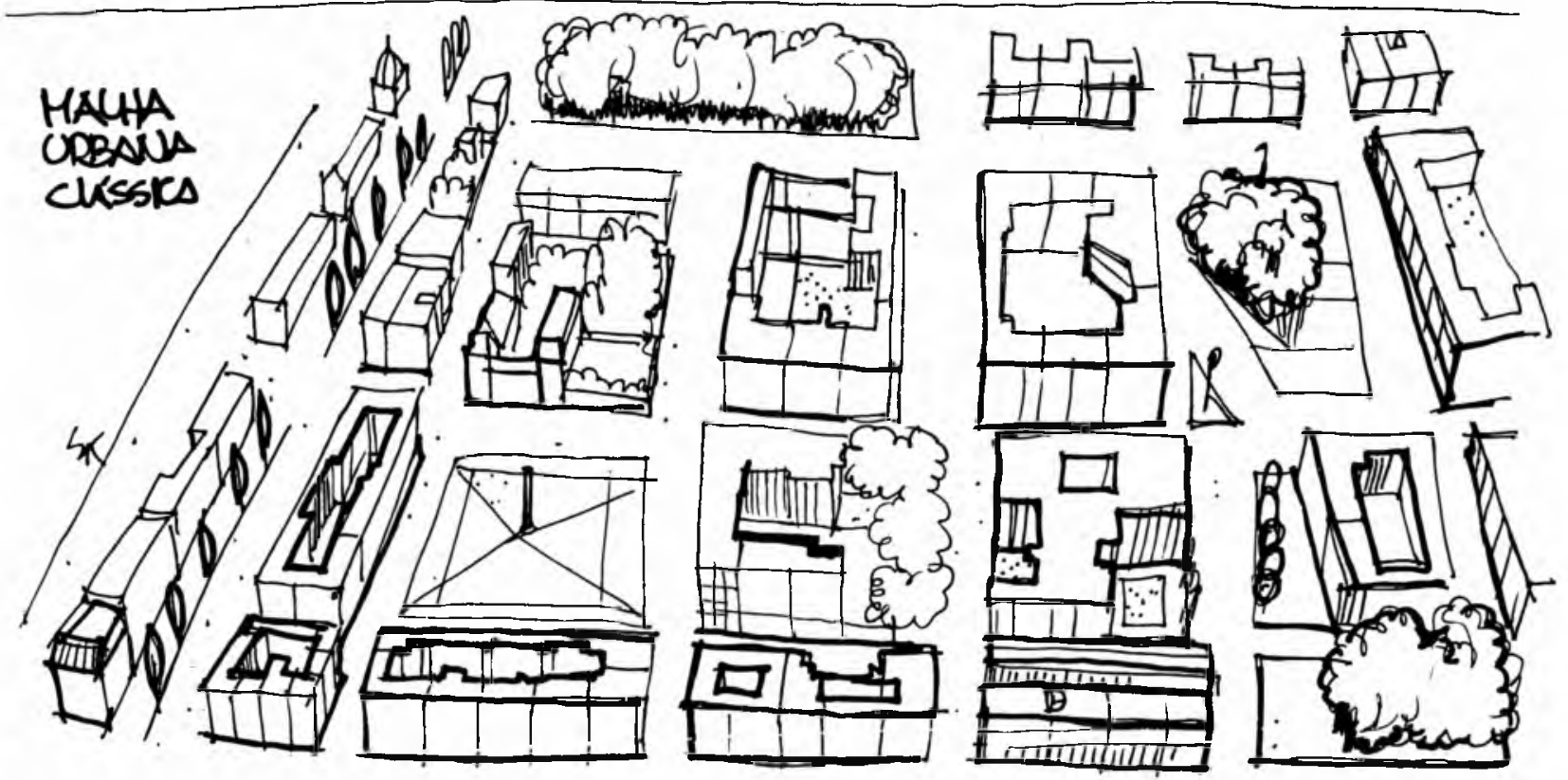




\section{OS ESPAÇOS LIVRES MODERNOS}

No Brasil, na década de 50, surgiram e se consolidaram no país as principais linhas do projeto paisagístico contemporâneo, sendo, também, palco da idealização e da construção das mais radicais posturas referentes à conformação dos espaços livres urbanos.

Estas idéias, típicas do urbanismo moderno, previam como ideal um cenário urbano de prédios isolados imersos em um verde contínuo. A criação de Brasilia consubstancia no urbanismo brasileiro este ideário, que é adotado como padrão/em projetos urbanísticos por todo o país.

$\rightarrow E x$ TPi CO

A figura idealizada valoriza a criação de espaços livres morfologicamente indefinidos, de relvados e arvoredos, sob um fundo composto de um céu azul anil, permeando por estes pilotis de prédios isolados. Contesta-se a cidade tradicional e seus espaços hierarquizados em detrimento da fórmula aplicada na nova capital, na qual as superqua-
dras são os padrões, os modelos vivos.

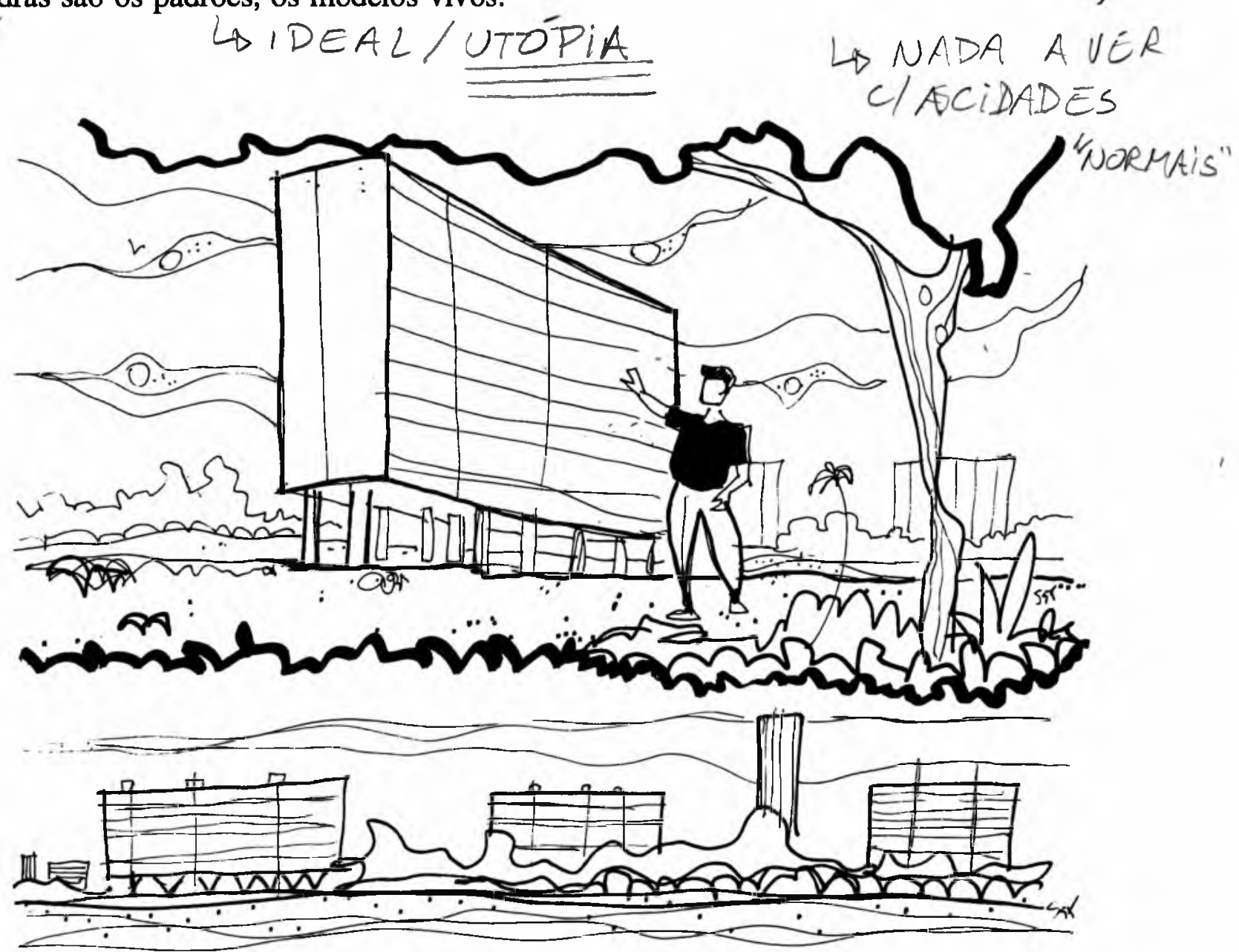


Se para a nova capital, hoje, 30 anos após sua fundação, estas fórmulas se mostraram relativamente eficazes, na cidade tradicional, quando aplicadas, se constituíram em fracassos reduntantes.

Mesmo em Brasília, o seu sucesso é parcial. pois dentro do plano piloto, onde tais configurações são bem aceitas pela populacão, observa-se uma grande quantidade de espaços "mortos", isto é, aqueles que praticamente nunca são utilizados pela população e a criação de uma hierarquia de caminhos e percursos, que de certo modo recuperam as hierarquias urbanas tradicionais ignoradas na sua concepção ${ }^{14}$

$\mathrm{Na}$ cidade convencional estes padrões, quando aplicados, praticamente obrigaram a população a uma intervenção drástica para adequá-las ao seu cotidiano. Este é um fato perceptível em qualquer cidade do país, que possua um conjunto habitacional construído por cooperativas ou companhias de habitação estatais (as conhecidas Cohabs). Nestes lugares, na medida do possível projetados dentro de cânones modernos, os primitivos espaços livres foram ocupados e re-hierarquizados, transformando a antiga configuração, de caráter modernista, em um espaço urbano, cuja configuração é similar ao da cidade tradicional. Criaram-se para tanto os planos verticais necessários redividindo-se ou renarcelando-se os primitivos planos horizontais de piso ${ }^{15}$. RQUi -

Estas adaptações se mostram mais ou menos iguais em todos os pontos. Os exemplos, mostram no caso, um trecho do conjunto habitacional de Carapicuíba na Grande São Paulo, que teve seu projeto urbanístico de caráter modernista e, portanto, seus espaços livres, totalmente transformado em sua estrutura morfológica pela população.
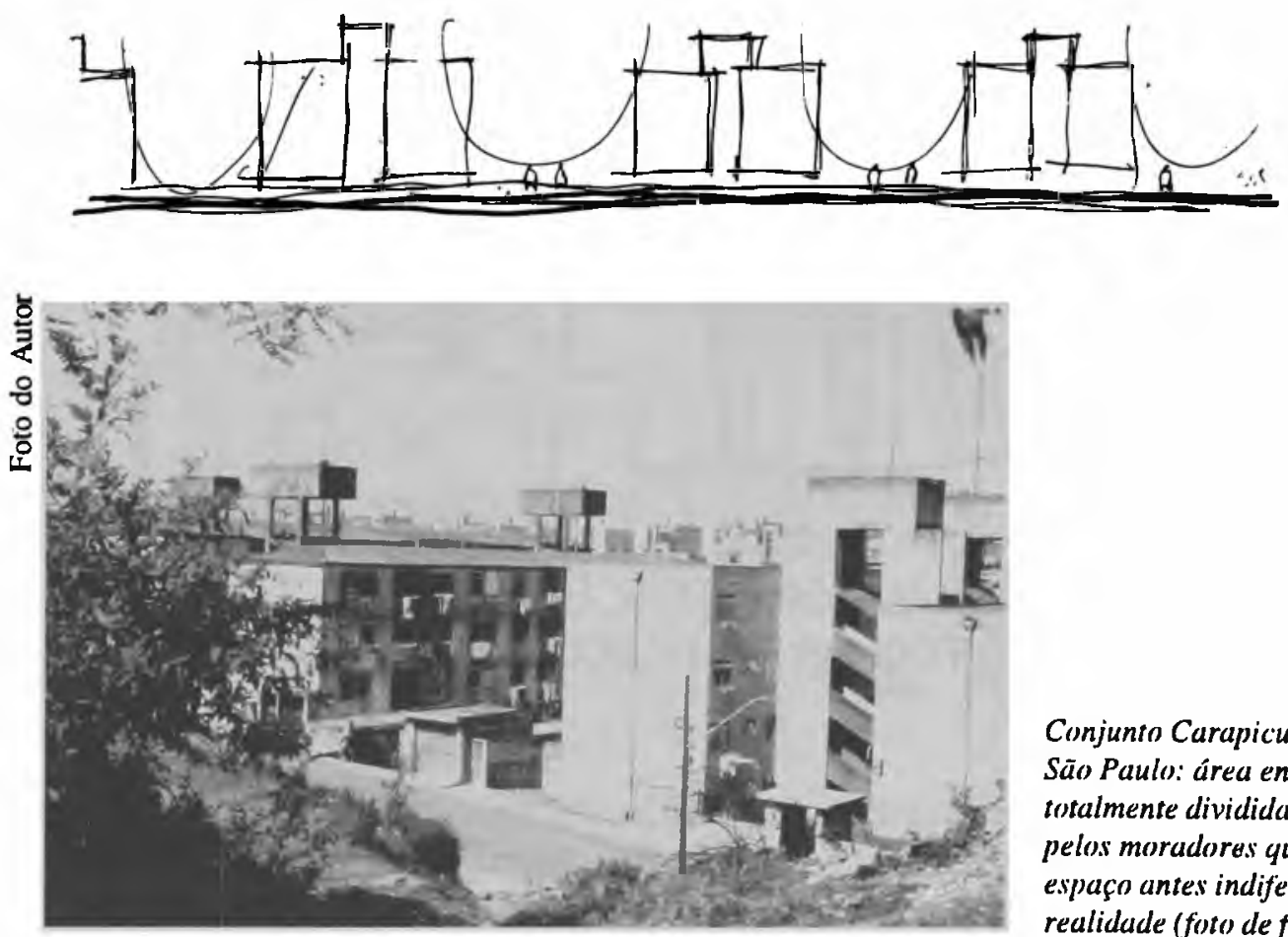

Conjunto Carapicuiba na Grande São Paulo: área entre prédios totalmente dividida e subdividida pelos moradores que adequam o espaço antes indiferenciado à sua realidade (foto de fevereiro de 1995) 
Estes fatos e outros mais levam a concluir que a imagem "modernista" de espaco livre urbano verde e fluido é ineficaz para uma futura conceituação e concepção de novos espaços. Esta deve ser substituída por uma visão menos romântica e mais objetiva, que vise atender às diferentes necessidades sociais de 11Sa de tais espacos, de modo a sobrepujar tais conceitos e se utilizar oưưs novos e mais adequados à vida urbana contemporânea.

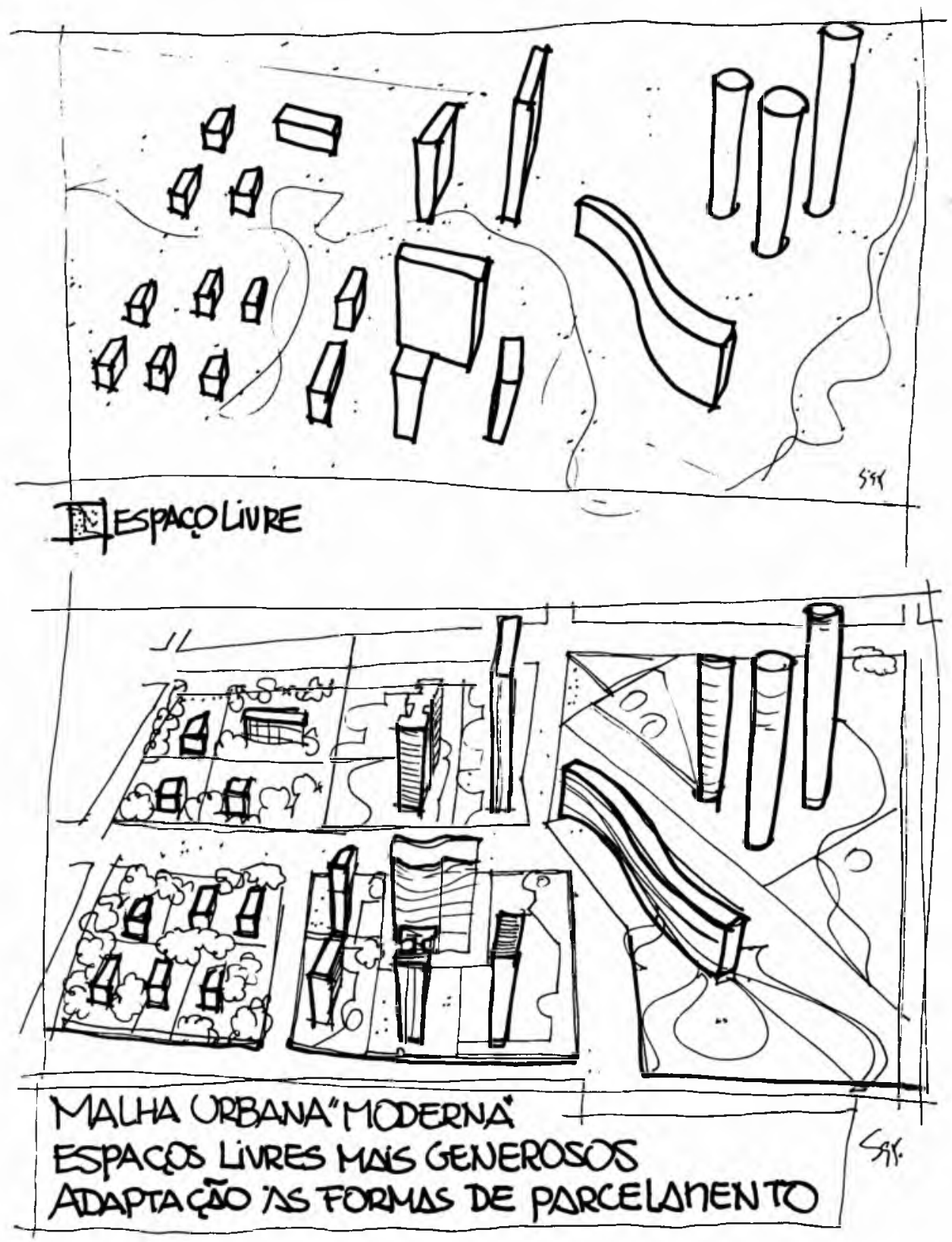

No geral, a cidade brasileira apresenta uma série limitada de padrões construtivos de espaços livres de edificação e dentre estes, a ruąé, com certeza, o mais definido de todos os seus espaços públicos. 
Seus padrões foram, durante todo o século 20 , consolidados, criados, recriados e contestados e ao final do século se mostram bastante eficientes. Foram criadas as figuras da rua-corredor, da rua-jardim e outras mais. A rua-jardim, arborizada, com calçadas gramada e configuradas por prédios, altos ou baixos, isolados, se torna o arquétipo, $\mathrm{o}$ modelo de espaço público, sendo eleita como padrão de moradia das elites.

A colaboração mais direta do urbanismo moderno à cidade tradicional não está contida dentro dos limites dos espaços livres públicos e sim dentro do lote e da quadra urbana, onde o edifício isolado dos demais é considerado como um padrão ${ }^{16}$. A adoção deste padrão leva durante todo o século 20 , em especial na segunda metade, a uma drástica transformação da morfologia urbana da cidade convencional, e que se associados a um padrão de ocupação, de loteamento do solo bastante definida, redirecionam o desenho das novas paisagens urbanas no país.

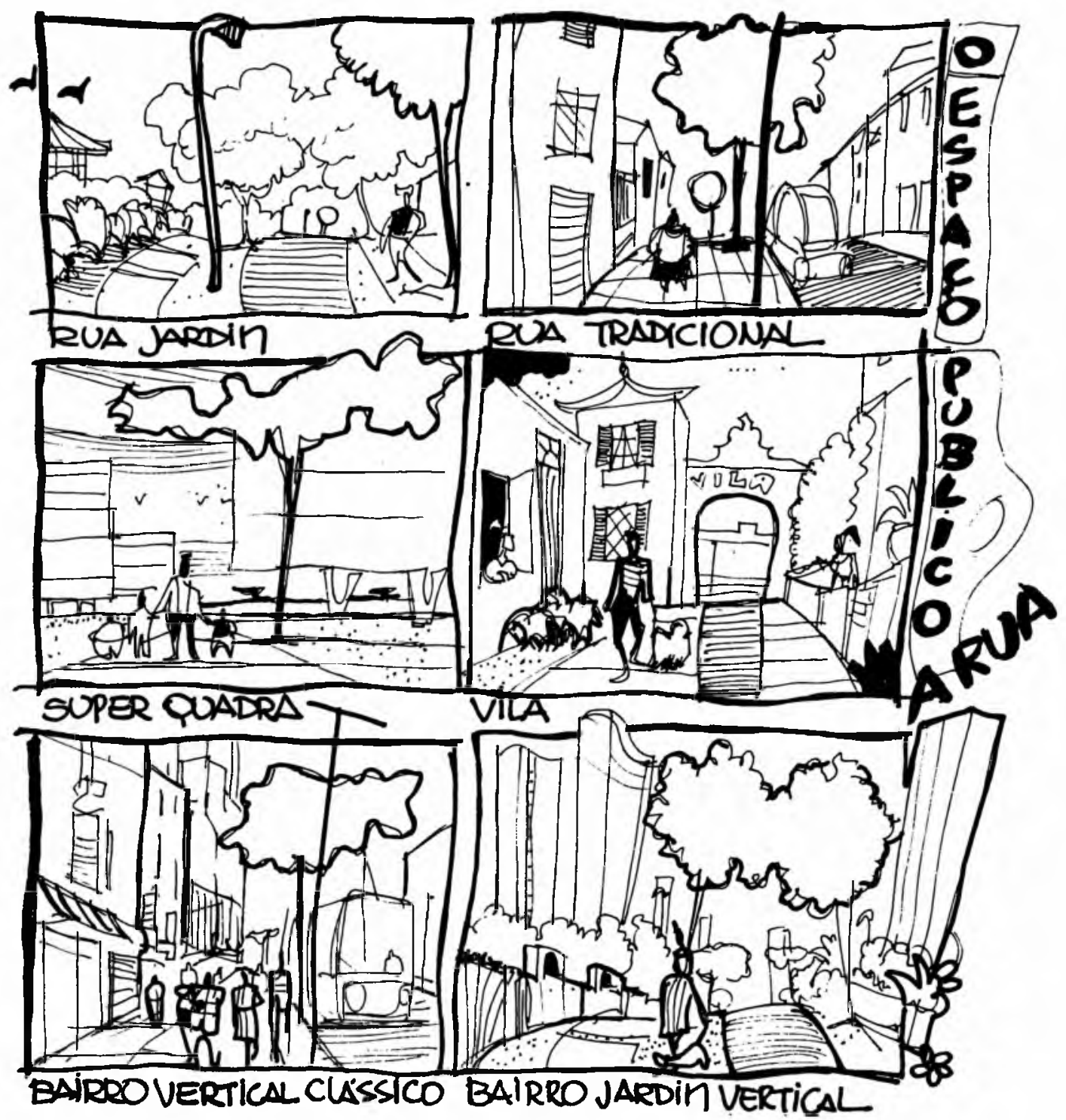




\section{- cenario IDEAL}

\section{olote o jadar o ediacio O bajRrosardin}

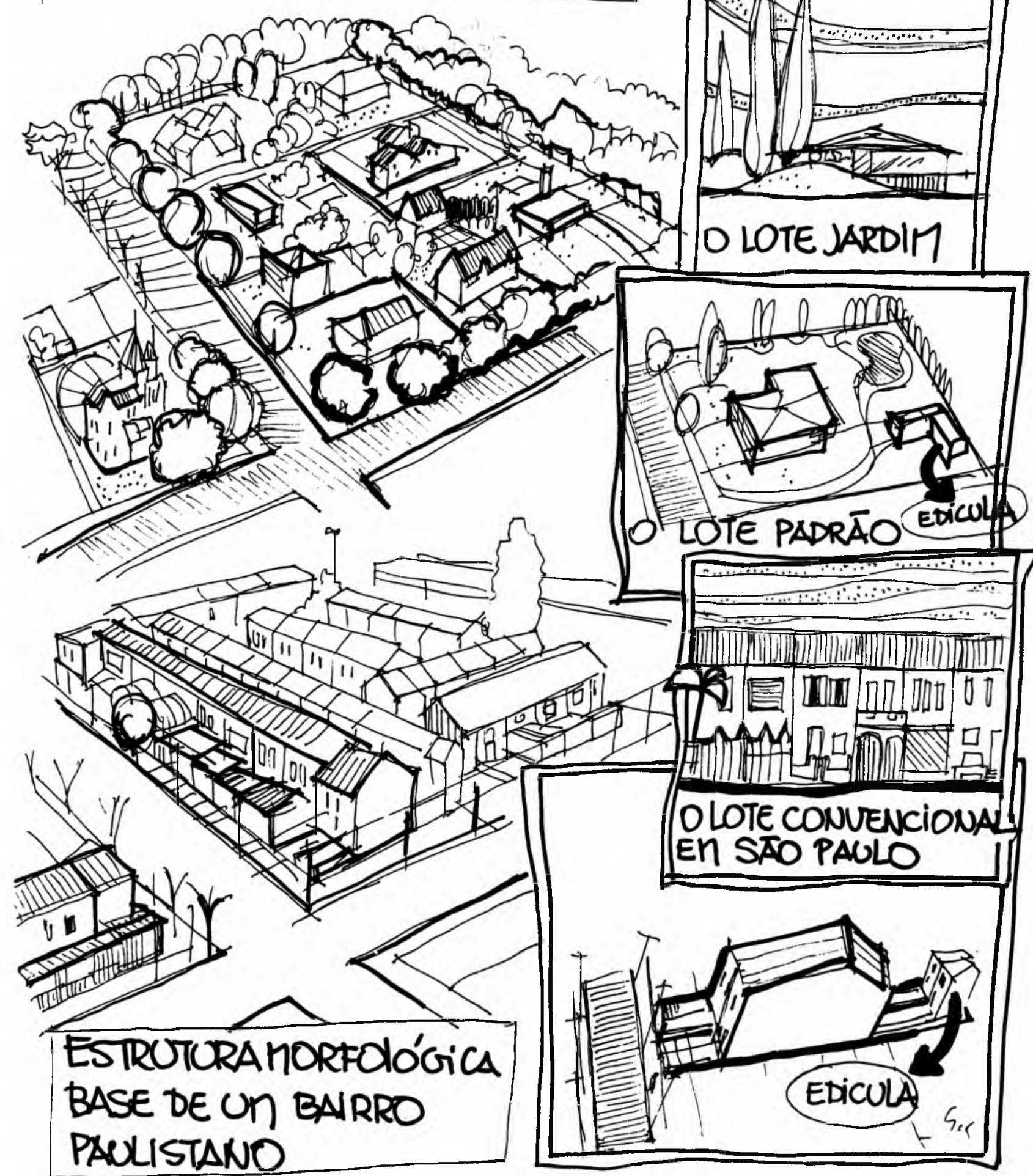




\section{ESPAÇOS LIVRES DE EDIFICAÇÃO E PADRÕES URBANOS}

Os elementos definidores dos espaços livres de edificação são os mesmos em qualquer ponto em que se esteja - construções, edifícios, muros, escadaria, vegetacão, arvoredos. bosques, árvores isoladas, sebes, arbustos, etc., formas de relevo, águas, seres vivos. veículos e homens, todos diretamente colaboram na composição destes espaços, variando sua participação de acordo com o contexto e o lugar em que se inserem formando planos, paredes e pisos e constituem lugares de vivência de contemplaçą) eoriservaçao encontros Estes elementos obedecem a logicas diversas de associaçăo, sempre vinculadas a formas de parcelamento e, portanto, de propriedade do solo.

As formas de apropriacāo. de parcelamento do suporte físico condicionam toda a constituição morfológica urbana. A morfologia da paisagem resultante de acordo com o extrato social que as implementa, diferenciando-se, ao menos de um modo sutil, entre si. Por exemplo, nos bairros-jardins brasileiros que têm como padrão referencial o subúrbio americano (como os bairros de Alphaville ou Jardim América em São Paulo), têm uma conformação diferenciada entre si e entre o modelo, devido a vários fatores como hábitos sociais e faixas de renda de seus usuários e do país, especificidades de vegetação, tamanho de lotes. arquitetura, etc. fazendo com que, apesar da aparência similar, possuam uma (identidade própria) Esta identidade pode ser percebida nas formas de plantio. na escolha da vegetação, no estilo da arquitetura, tamanho das calcadas e ruas. que se comportam e configuram dentro de uma identidade local e nacional.

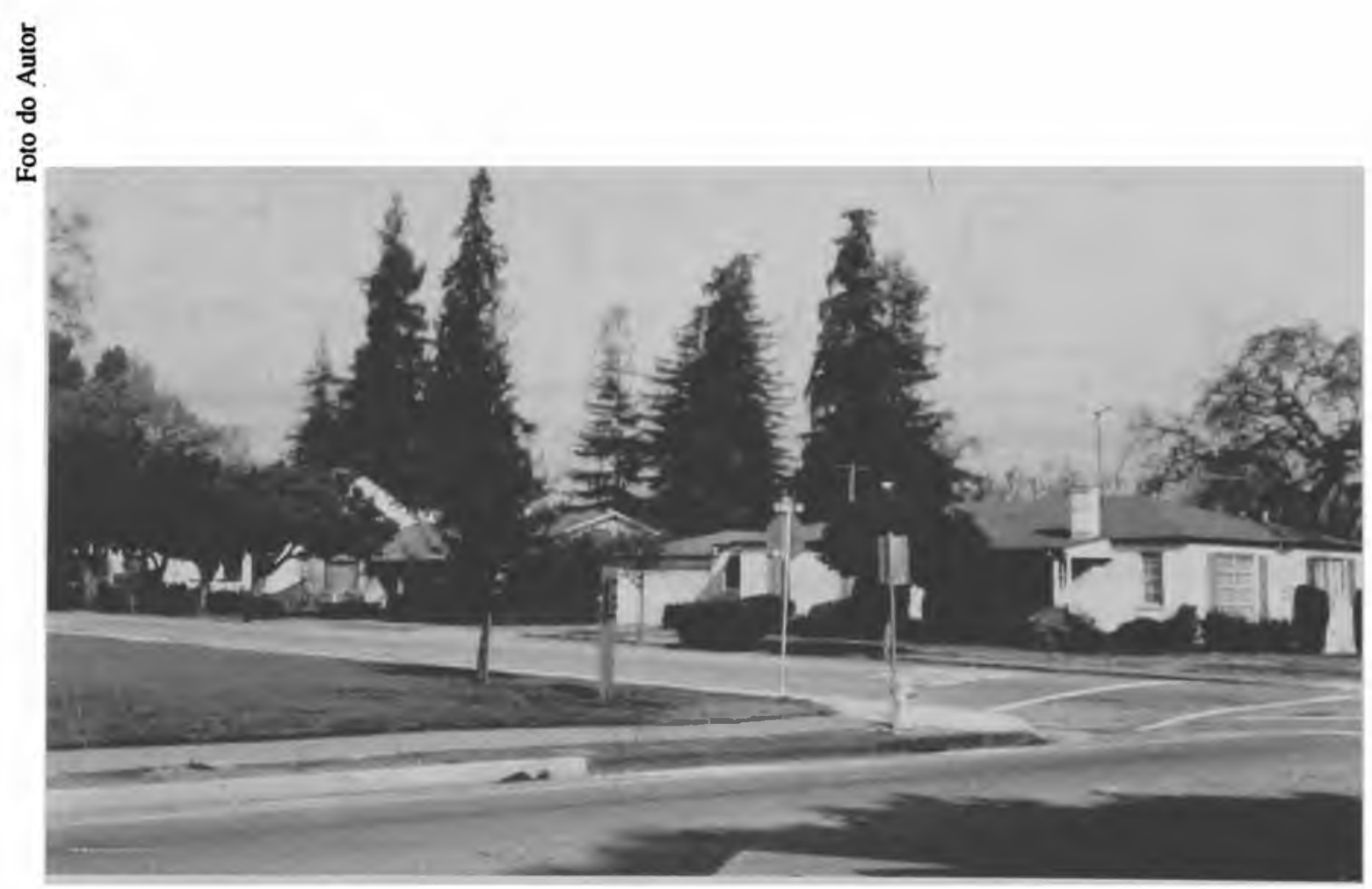

Vista de uma rua típica de subúrbio americano - San Carlos, Califórnia 
Os espaços livres de edificação brasileiros se estruturam basicamente em função de uma forma quase única de parcelamento do solo, que privilegia os lotes alinhados lado a lado. tendendo a retangulares e possuindo as laterais maiores, perpendiculares às vias públicas.

Por todos os pontos do país se encontram tais situações, em especial em áreas habitacionais, com exceção das áreas industriais, das chácaras urbanas (às vezes), das superquadras de Brasília e dos conjuntos habitacionais.

Todo o ideário está centrado na existência do prédio colocado ao meio do lote. Este foi gerado no fim do século passado com a figura do palacete implementado no início do século e consolidado como o espaço ideal para a moradia na figura e contexto do bairro-jardim ${ }^{17}$

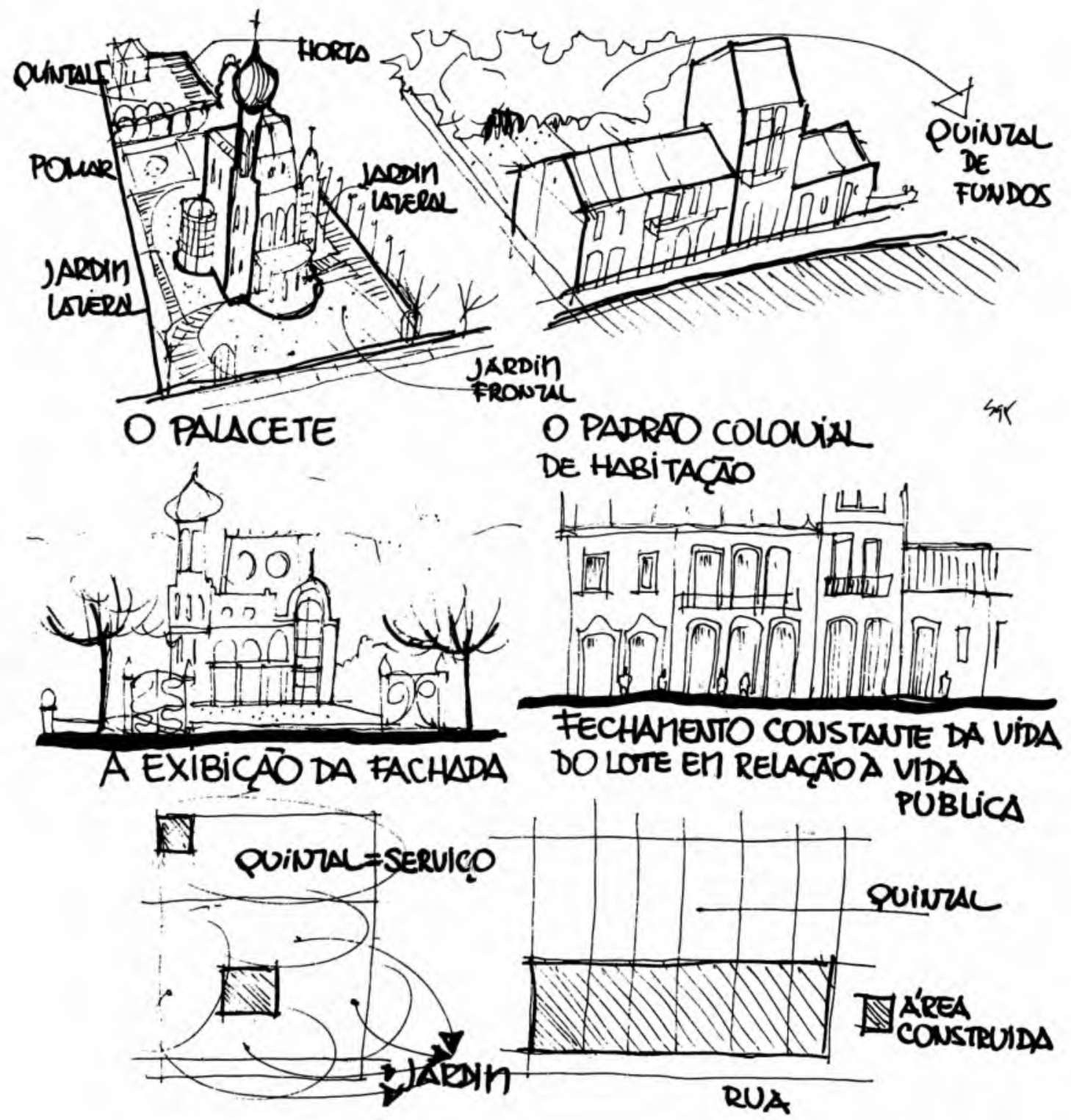


$\mathrm{O}$ ardim o uintal são as figuras urbanas características do século 20 na cidade brasileira e o lote descrito é o modelo.

A impossibilidade social de se adquirir um lote com um bom padrão dimensional, que permita a conłtrução de edifícios isolados faz surgir uma série de situações derivadas e entre elas o-ppequeno lote, ocupado por sobrado geminado, com recuo frontal e de fundos, típico dos bairros de classe média de São Paulo.

LDQUINTAL

Por todas as cidades do país variações morfológicas são implementadas, sendo praticamente abandonado o padrão colonial de assentamento (ainda encontrado e nas cidades históricas nas áreas mais antigas das cidades).

\section{A RUA PADRÃo}

A rua modelo da cidade brasileira, que serve de referência a todas as outras é aruajardim Deriva dos velhos boulevards no início do século e para o qual se voltaram os palacetes dos barões de café e da elite do Império (caso das avenidas Paulistas e Higienópolis em São Paulo).

São vias largas, com calcadas aiardinadas e arborizadas que, desenhadas pela primeira vez para os bairros-jardins construídos pela Cia. City) São Paulo, na segunda década do século 20, podem ser encontradas por todos os bairros ricos do país.

No restante da cidade, somente a arborizacão de rua permanece como um padrão de organizacão espacial constante e se espalha por todo o país a partir das últimas décadas do século 20 . São as ruas corredor ${ }^{18}$.

\section{MODELOS E MODELOS}

As configurações paisagísticas urbanas podem ser distinguidas entre aquelas típicas de áreas verticalizadas e áreas horizontalizadas.

A geração dos espacos livres nas áreas verticalizadas seguiu, a princípio, padrões diferentes das áreas horizontais baseando-se em uma forma urbanística derivada do urbanismo francês que foi adotada para as(áreas centrais das principais cidades do país, como Rio de Janeiro, Recife, Belo Horizonte, Porto Alegre e São Paulo. O padrão de loteamento é o mesmo das demais quadras, mas o padrão de assentamento dos edifícios é diferenciado, estando todos os prédios alinhados na rua, geminados, formando pátios internos dentro das quadras. destinados apenas à ventilacão e insolacão dos predios ou de eventuais quintais. Surgindo crua "destiladerro e uma estrutura morfologica urbano/paisagística típica, que configura além das áreas centrais também grande parte 
das áreas litorâneas da cidade do Rio de Janeiro (em especial o trecho entre Copacabana e o centro), tornando-se um modelo nacional para áreas verticalizadas.

Os inconvenientes desta estrutura morfológica são apontados e questionados a partir da metade do século pelos partidários do movimento urbanístico moderno e surge como vanguarda, a idéia, aceita a princípio pelas elites paulistanas, da construcão do prédio isolado no lote.

Esta configuração primeiramente confinada a segmentos específicos das cidades, no caso de São Paulo, aos bairros "jardins" e "Higienópolis" se espalha pelo país e é confirmada em diversas legislações urbanísticas.

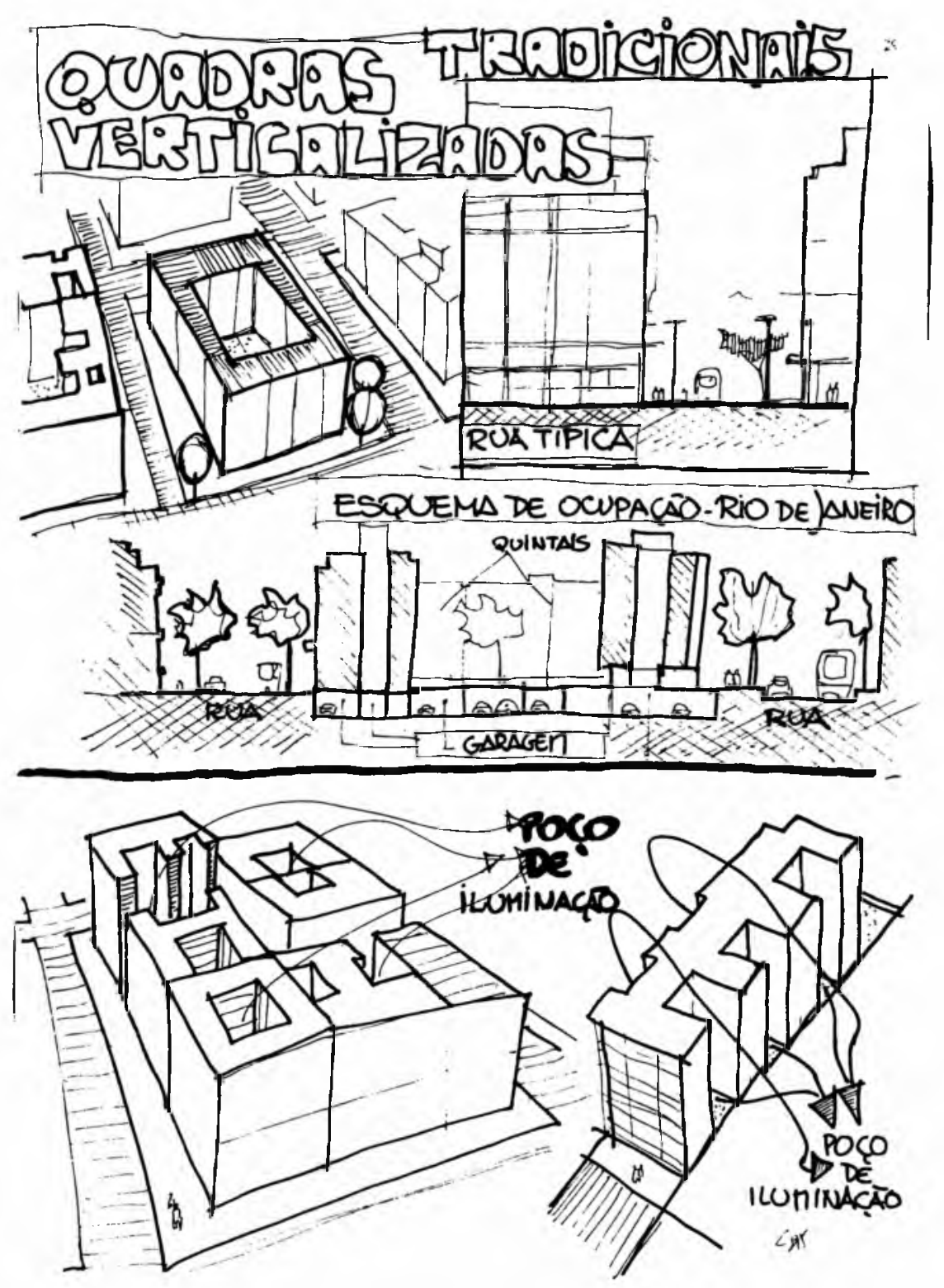




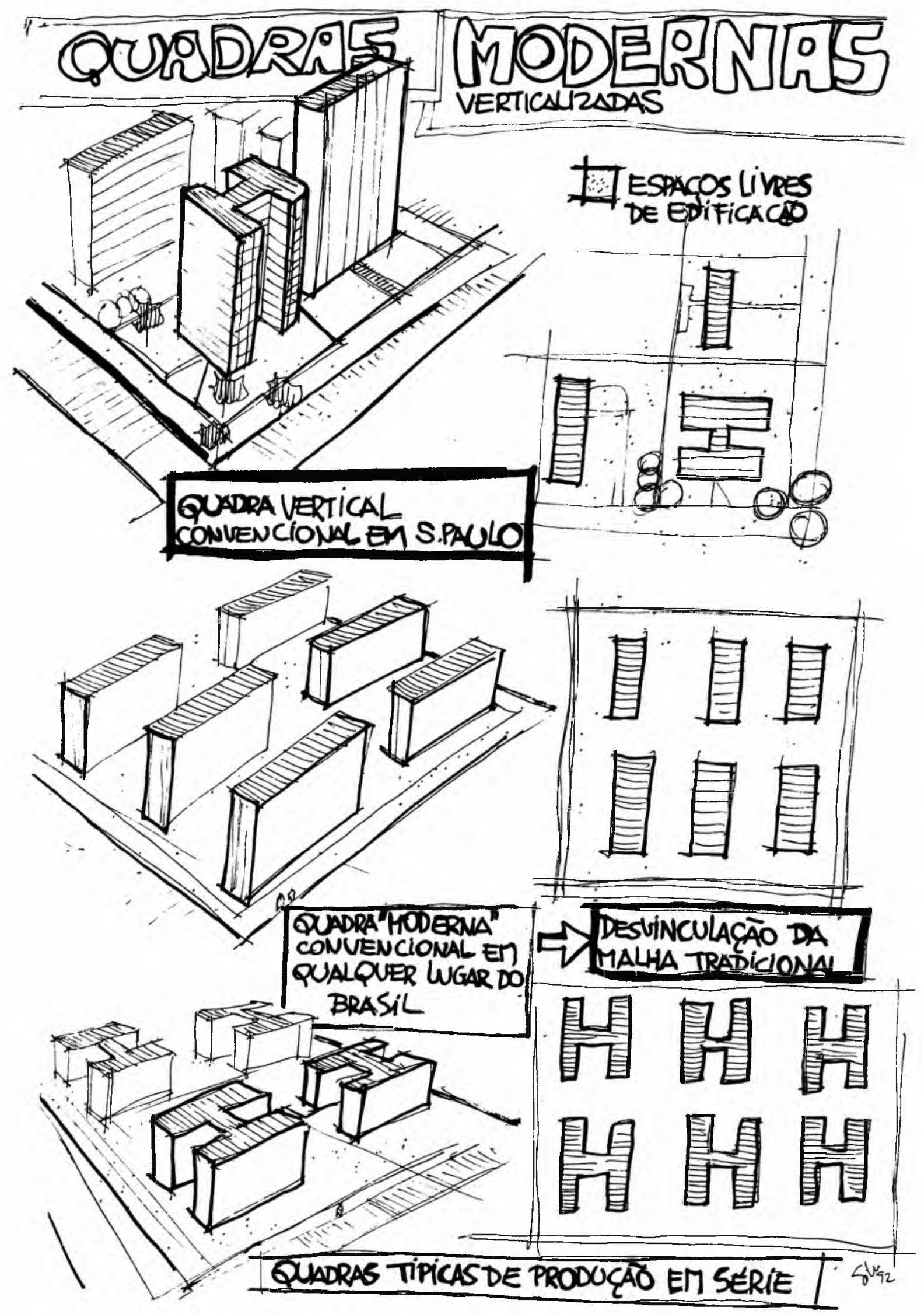

Paisagem Ambiente Ensaios São Paulo n. 7 p. 15 - 56 jun. 1995 
-SPACOS LIVRES E VERTICALIZACAO

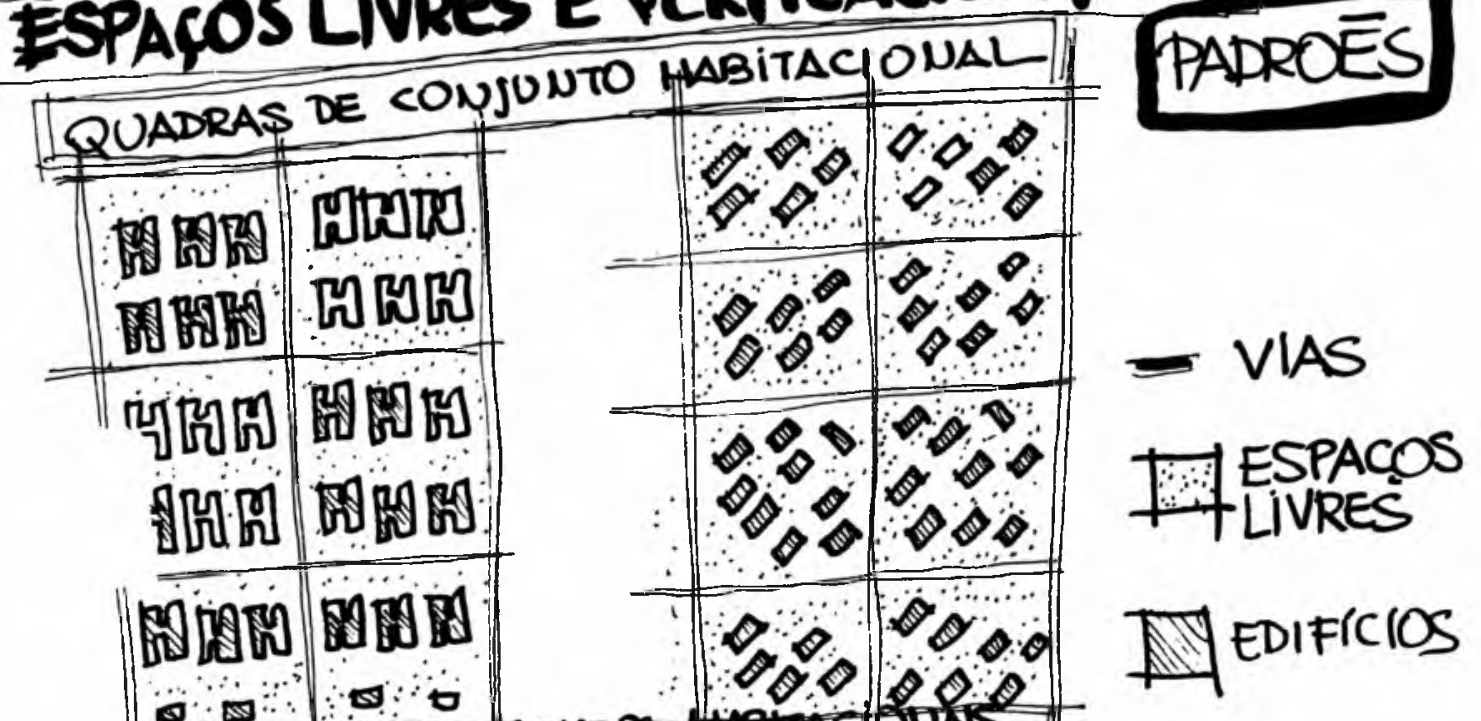

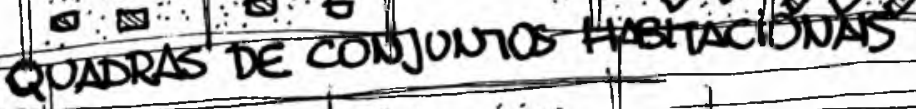

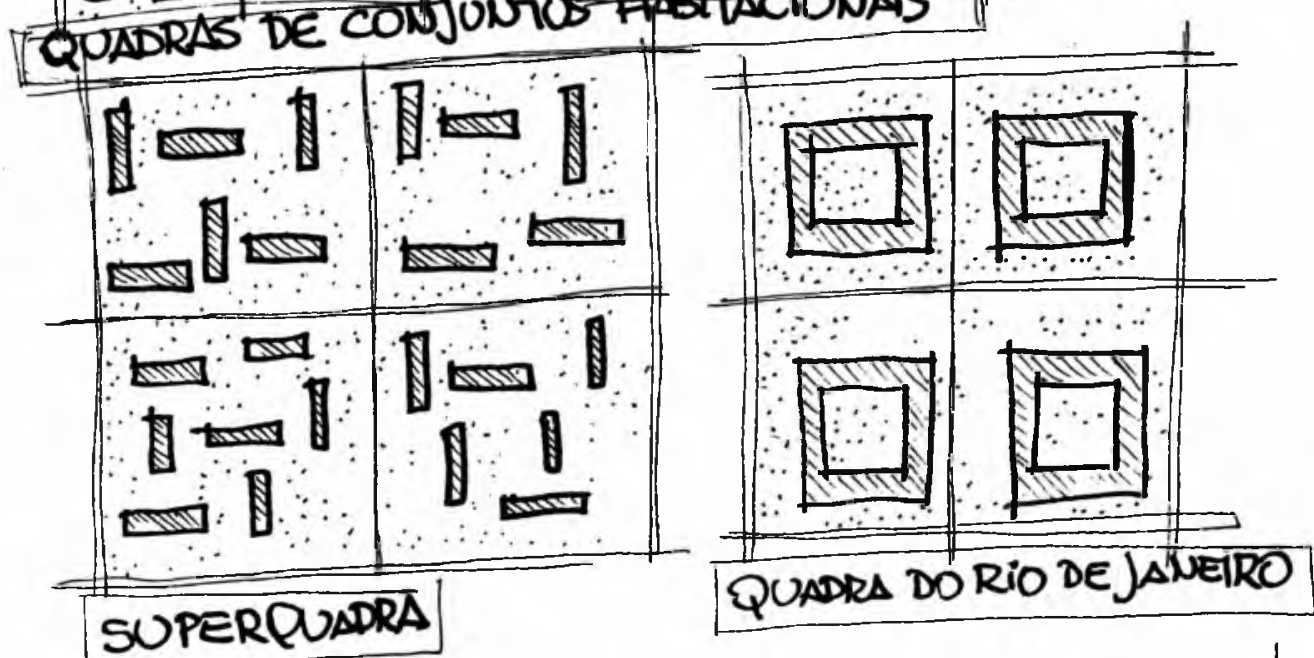
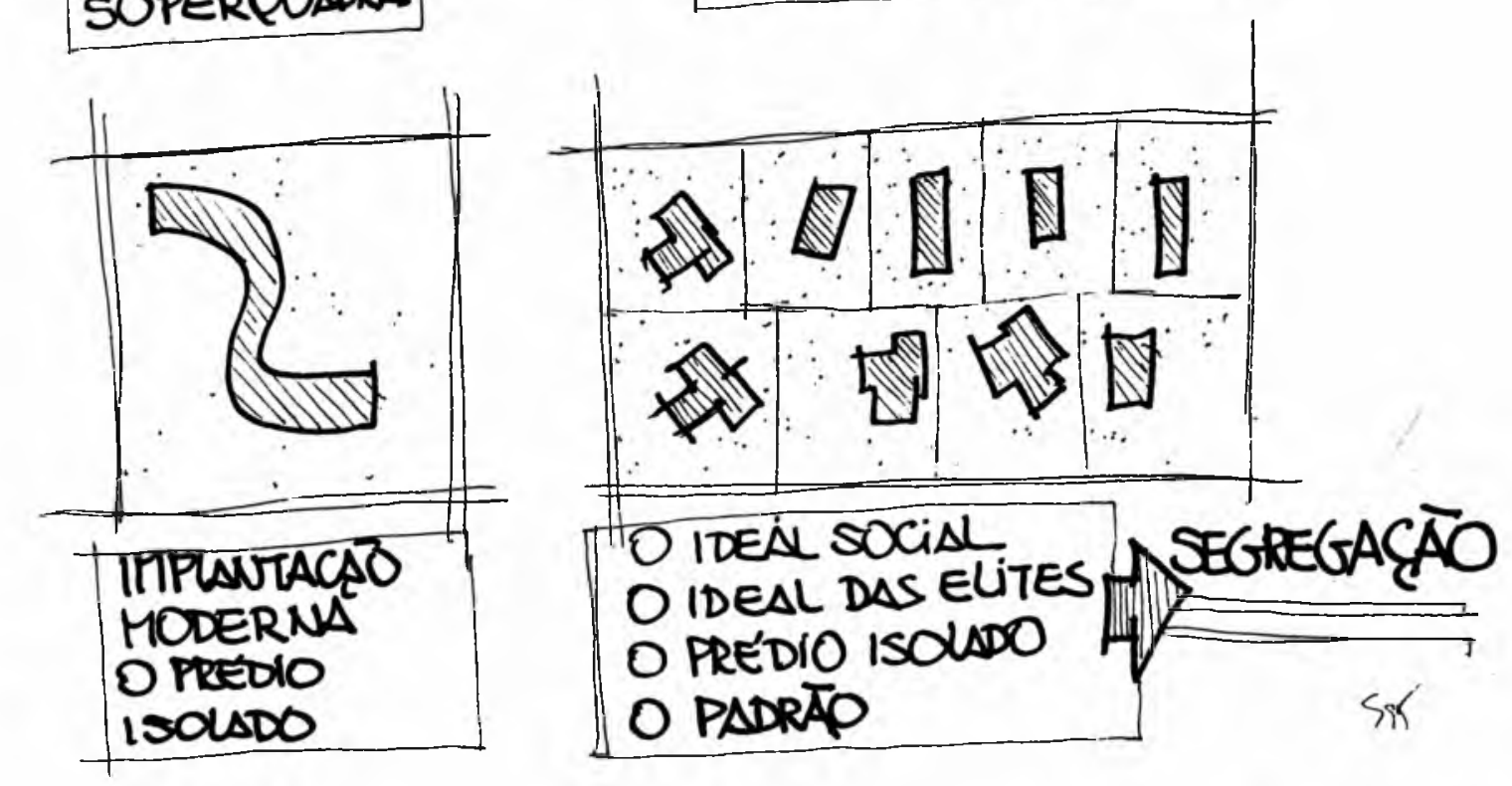
Como decorrência tem-se hoje a figura do hairro-iardim vertical impressa em tecidos urbanos significativos (Campo Belo e trechos de Higienópolis em São Paulo, Camburi em Campinas e outros mais) com ruas margeadas por prédios isolados em relação aos muros dos lotes, entremeados de iardins e cercados por gradis de ferro.

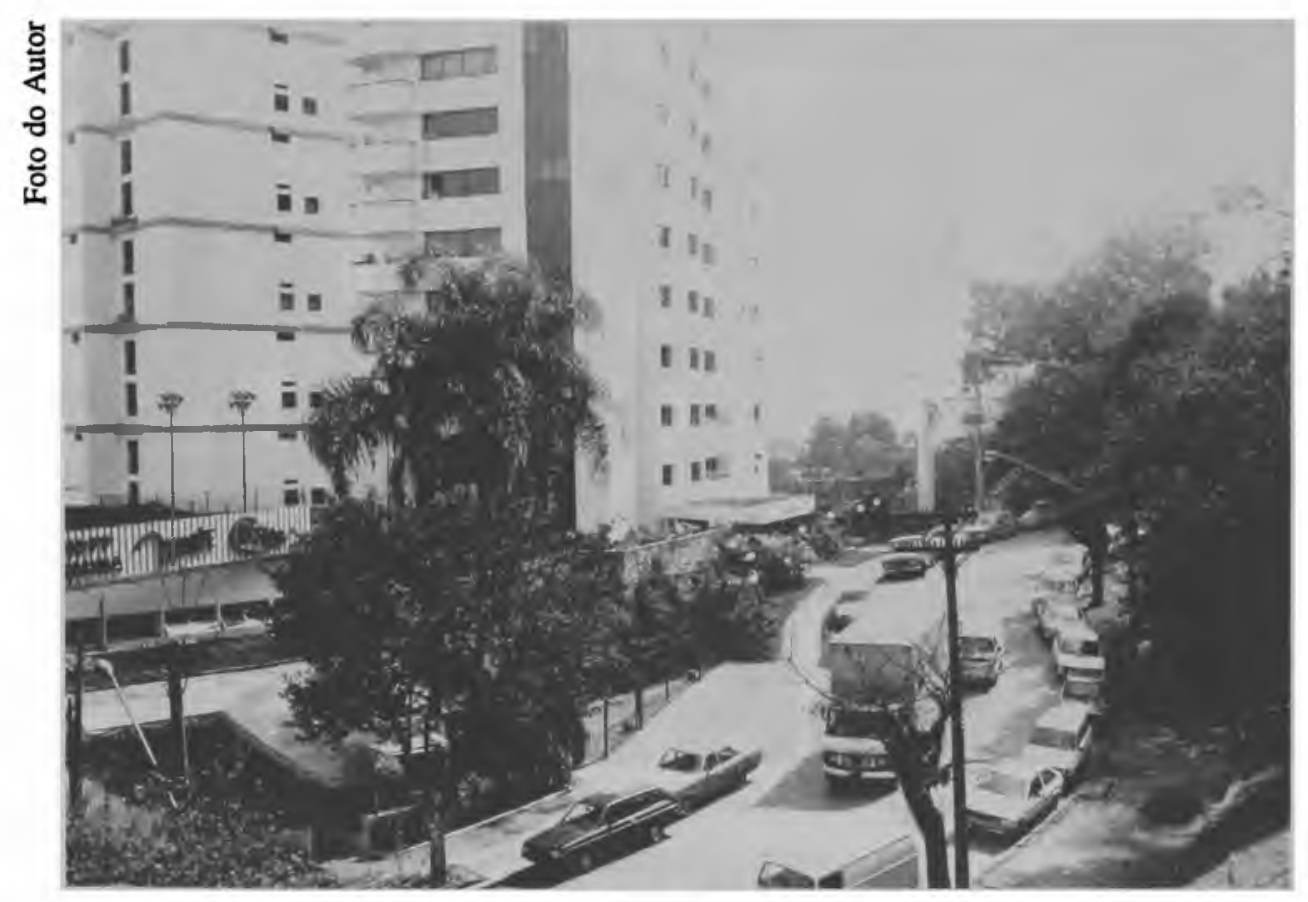

Rua Edgar E. de Souza, Pacaembu, Sāo Paulo: é um caso típico de rua jardim verticalizada

Diversas outras formas morfológicas foram geradas se contrapondo aos esquemas clássicos do Império e da Primeira República e os croquis a seguir mostram alguns modelos de assentamento gerados. Destes todos, os que melhor se adaptaram à realidade urbana foram como vimos aqueles enquadrados dentro dos padrões mais tradicionais da rua corredor e da rua jardim, que apesar de questionados e discutidos por décadas continuam sendo paradigmas projetuais. Todo e qualquer novo loteamento ou projeto urbanístico obedece então a estes padrões construtivos básicos ${ }^{19}$

A efetivacão deste modelo teve como apoin na cidade de São Paulo, toda uma legislação urbanística, que é criada especialmente, tendo como exigência principal, o recuo obrigatório restringindo a ocupacão pelo edifício a $50 \%$ ou menos da área do lote. Nesta cidade, se exige hoje, em grande parte de sua área, taxas de ocupação baixas que condicionam a existência de generosos espaços livres privados.

Este modelo é adotado indistintamente para o todo urbano e, mesmo nas novas áreas fabris, os espaços livres ajardinados são a tônica, de certo modo, um paleativo visual e uma panacéia aos reais impactos ambientais (poluição sonora, do ar e da água) causadas pelas fábricas. Passam a fazer parte do rol de exigências para o espaço de uma fábrica moderna, ajudando a melhorar a imagem da empresa. São espaços muitas vezes vastos, gramados e cuidadosamente plantados com arbustos e árvores floridos e que podem possuir projetos de paisagistas especialmente contratados. 


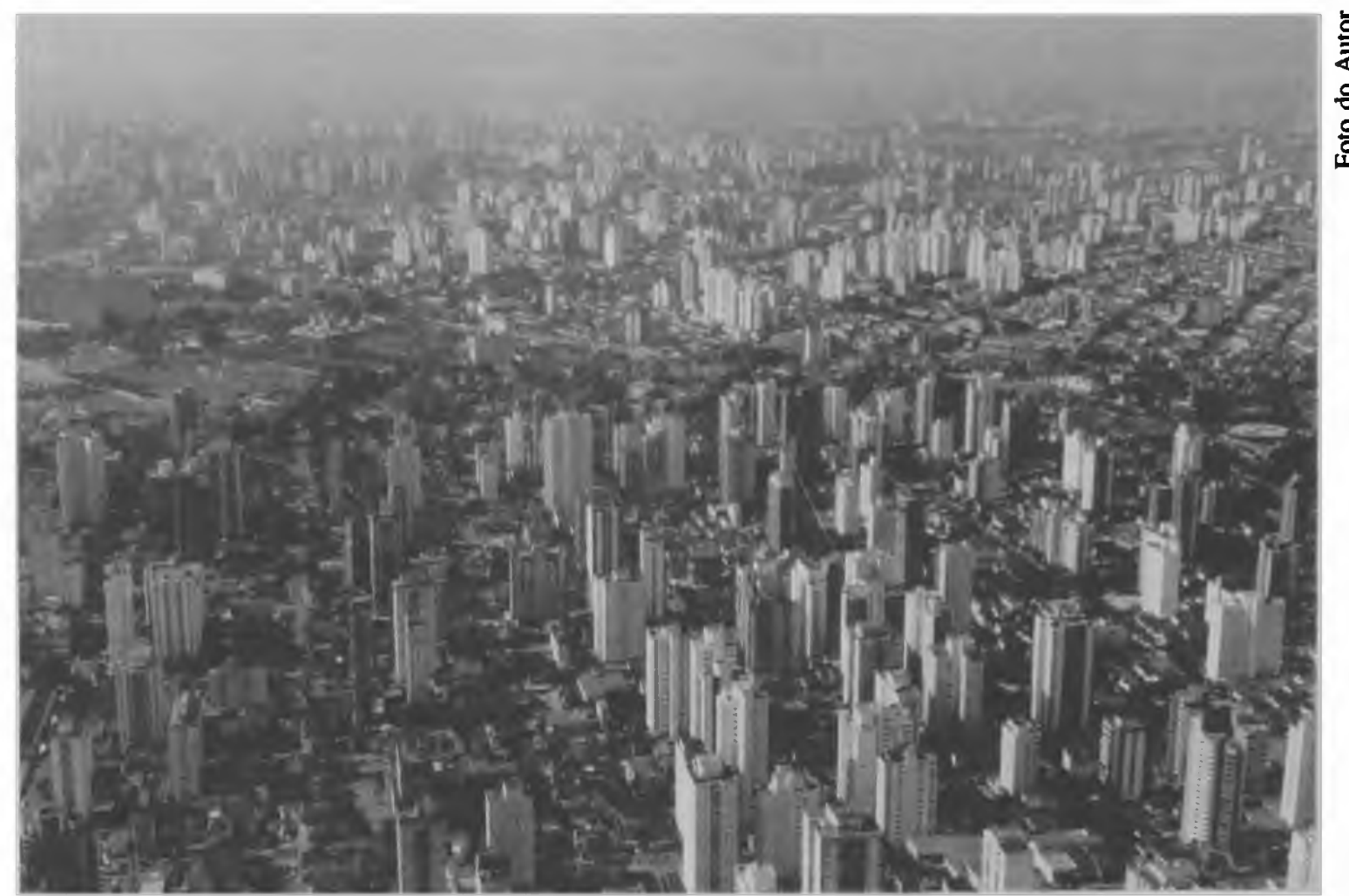

Vista geral do bairro de Moema em Sāo Paulo: modelo de paisagem verticalizada consolidado

Esta generosidade aparente de espaços livres dentro de parte dos lotes da cidade formal, não é acompanhada dentro da cidade informal, ou seja aqueles segmentos urbanos constituídos à revelia dos poderes legais. Lotes pequenos, construções precárias e uma superocupação do lote, que condiciona ao acoplamento das construções, deixa a disposição exígüos espaços livres, tanto dentro dos lotes (são praticamente inexistentes), como nas vias de acesso e circulação.

Paralelamente, em quase todas as cidades do país inexistem programas reais de implementação de sistemas de espaços livres de edificação destinados seja ao lazer, seja à conservação de mananciais ou encostas, sendo que, em parte dos casos, nem estão contidos em planos urbanísticos.

Existe na cidade brasileira de médio e grande portes uma real escassez de tal tipo de espaço (uma metrópole, por exemplo, como Recife, além das praias, não conta com mais de meia dúzia de parques, esparsos dentro do tecido urbano) Brasília com seu plano piloto todo arborizado, as cidades praianas com seu sistema de praias (verdadeiros parques sem vegetação) e Curitiba são das poucas exceções a esta regra.

A cidade do Rio de Janeiro beneficia-se da sua condição de cidade praiana quando se faz uma avaliação do seu sistema de espaços livres e teve como Brasília, no seu passado recente de sede do governo federal, condições de desenvolver um sistema público de parques, praças e reservas florestais de porte. 
A situação em relação aos espaços livres de edificação da cidade brasileira é de crise latente. As soluções adotadas são em geral parciais e poucas vezes atingem o todo da população, e, com certeza, muito pouco aquela mais necessitada.

Observa-se, dentro das camadas mais ricas, uma busca de soluções próprias alternativas à crise em questão, com a criação cada vez mais intensa de espaços privados, que visam atender às necessidades emergentes.

A não formalização de um sistema completo de espaços livres para lazer, adequados, dimensionados, acessíveis e seguros se observa como resposta à internalização do lazer em praças, parques e clubes privados, que sob a forma de condomínios, de quadras e em lotes fechados cumprem as funções antes destinadas prioritariamente aos espaços públicos $^{20}$.

Como resultado, criou-se toda uma forma de tratamento dos espaços livres de edificação internos aos condomínios e quadras horizontais ou verticalizados que, gerados inicialmente nas grandes cidades como São Paulo (anos 80) e nos condomínios da Barra da Tijuca (Rio de Janeiro), são copiados e reproduzidos por todo o país e onde a diversidade e multiplicidade de usos, qualidade de todo o espaço livre, são trocadas por uma especialização funcional.

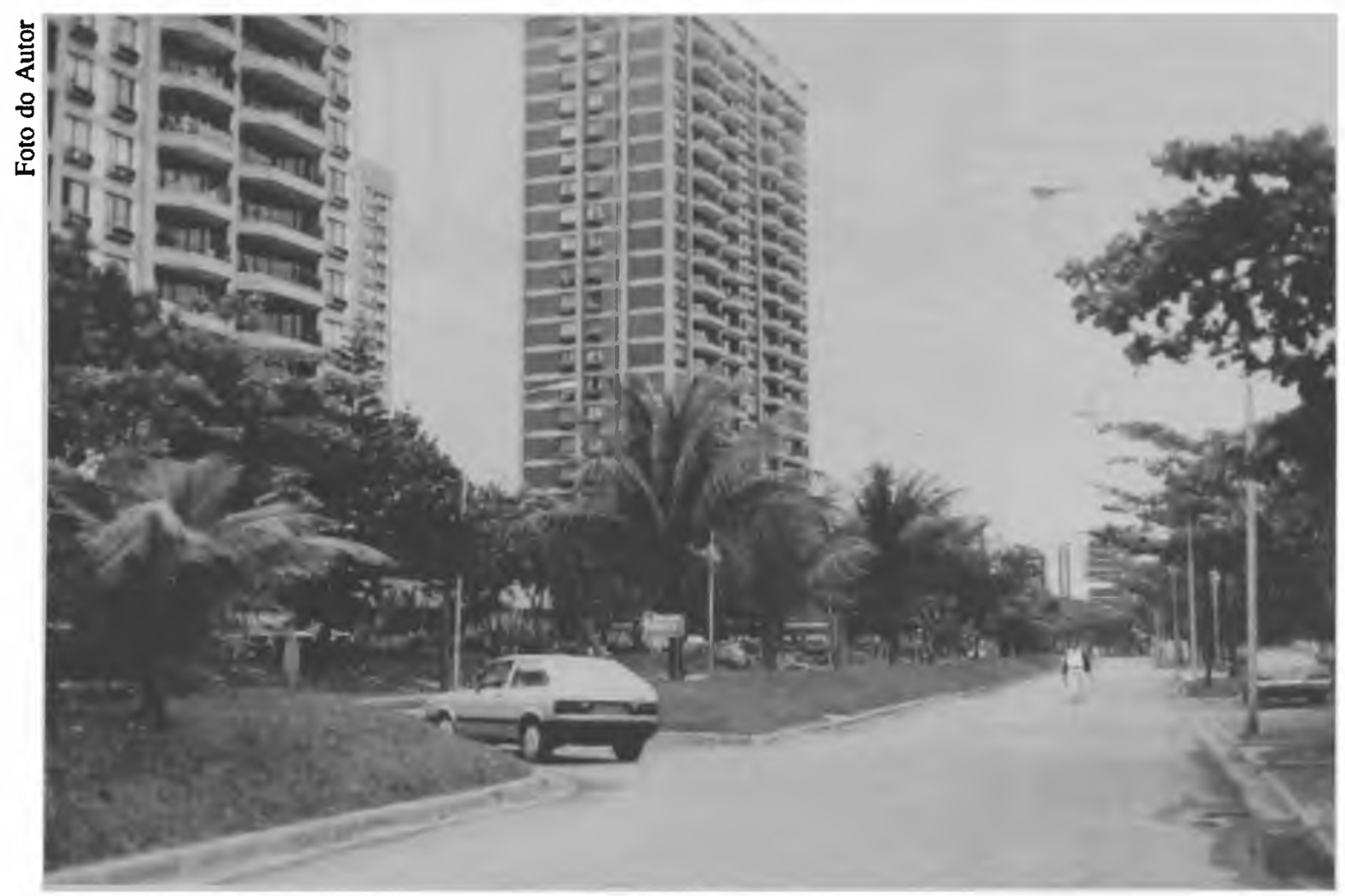

Os condominios na Barra da Tijuca no Rio de Janeiro, isolados, murados, com extensos jardins e áreas de lazer, ao mesmo tempo que para os seus moradores oferecem amplas possibilidades de convivio social, segregam sua comunidade do todo urbano 
Estes são espaços tratados especialmente para o lazer, com quadras poliesportivas, piscinas, jardins suspensos e áreas de estar, em muitas das vezes, objeto de projeto de paisagistas renomados.

Nas áreas mais pobres e mesmo naquelas destinadas à moradia de amplos setores da classe média a situação é inversa. Os espaços livres dos lotes e quadras são reduzidos e extremamente fragmentados, sendo utilizados ou aproveitáveis para atividades estritamente próximas dos moradores, como o lavar e secar roupas, ou o brincar de crianças pequenas. O lazer, quando possível, é feito nas ruas ou em espaços públicos mais distantes como praças e parques.

Os padrões de organização espacial dos mais ricos, paradoxalmente, são reproduzidos, como todos os demais, típicos das elites sociais, de um modo reduzido, e na medida do possível por todas as camadas sociais. O esquema gráfico a seguir mostra como a população de um conjunto habitacional, Cohab, recodifica e transforma seus espaços livres, seguindo os arquétipos das classes mais ricas, criando a seu modo cercas, pátios, guaritas, jardins e estacionamentos.

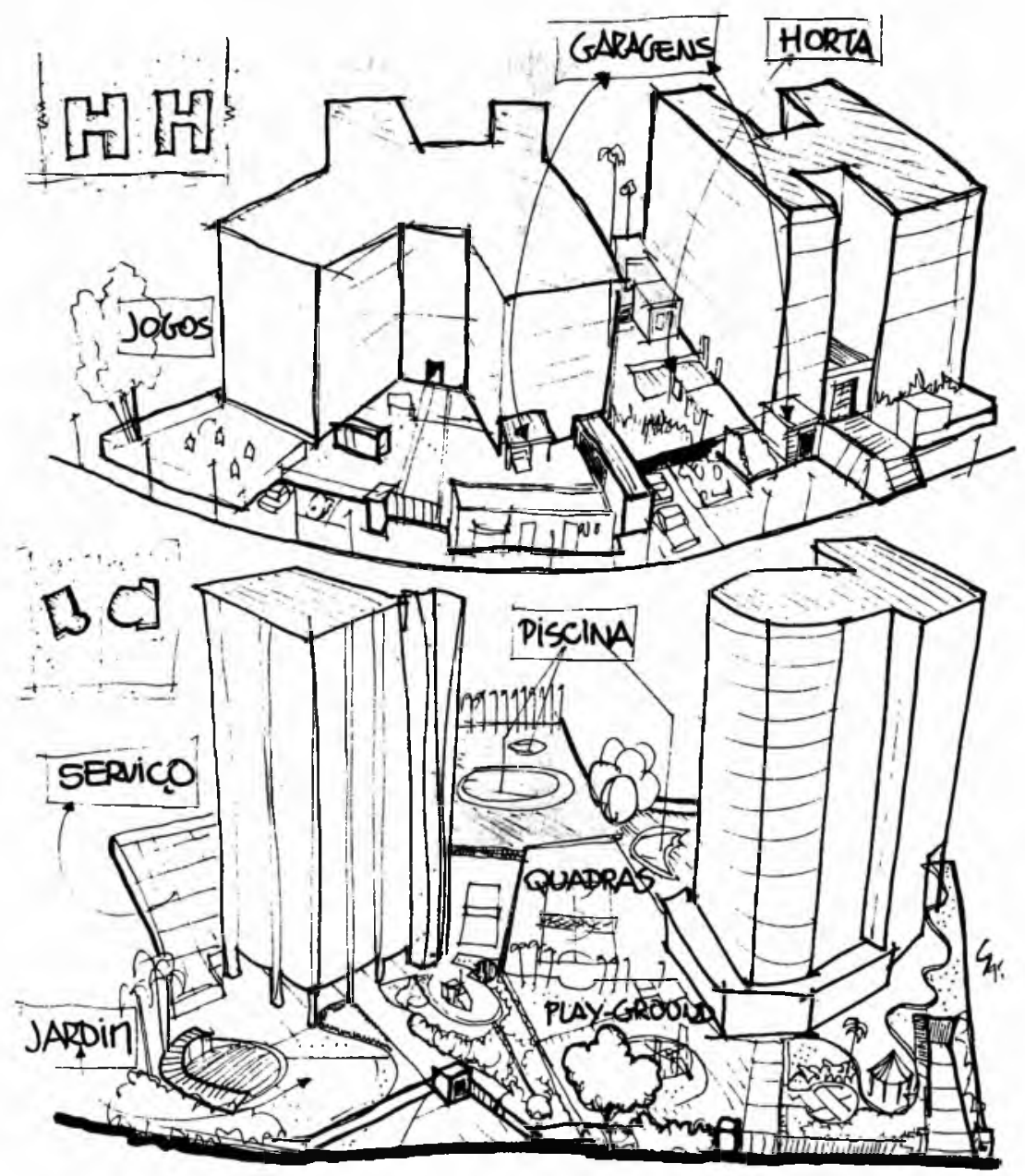


O país possui contradições sociais muito grandes e a geração dos espaços livres é resultado direto destas discrepâncias. Paralelamente, um modelo urbanístico único está praticamente implementado em todas as áreas urbanas modernas e ricas do território nacional. Toda a experiência urbanística de quatrocentos e tantos anos de urbanização e de adaptação aos diferentes climas e situações morfológicas está sendo superada por modelos gerados nas ricas cidades do sul e aplicados indistintamente por todas as partes.

O processo de ocupação urbana em qualquer instância ainda privilegia o binômio destruição e construção, e, muitas e quantas vezes ecossistemas importantes são substituídos por jardins urbanos, que tanto como os edifícios exigem para sua existência uma total remodelação dos terrenos e erradicação das matas.
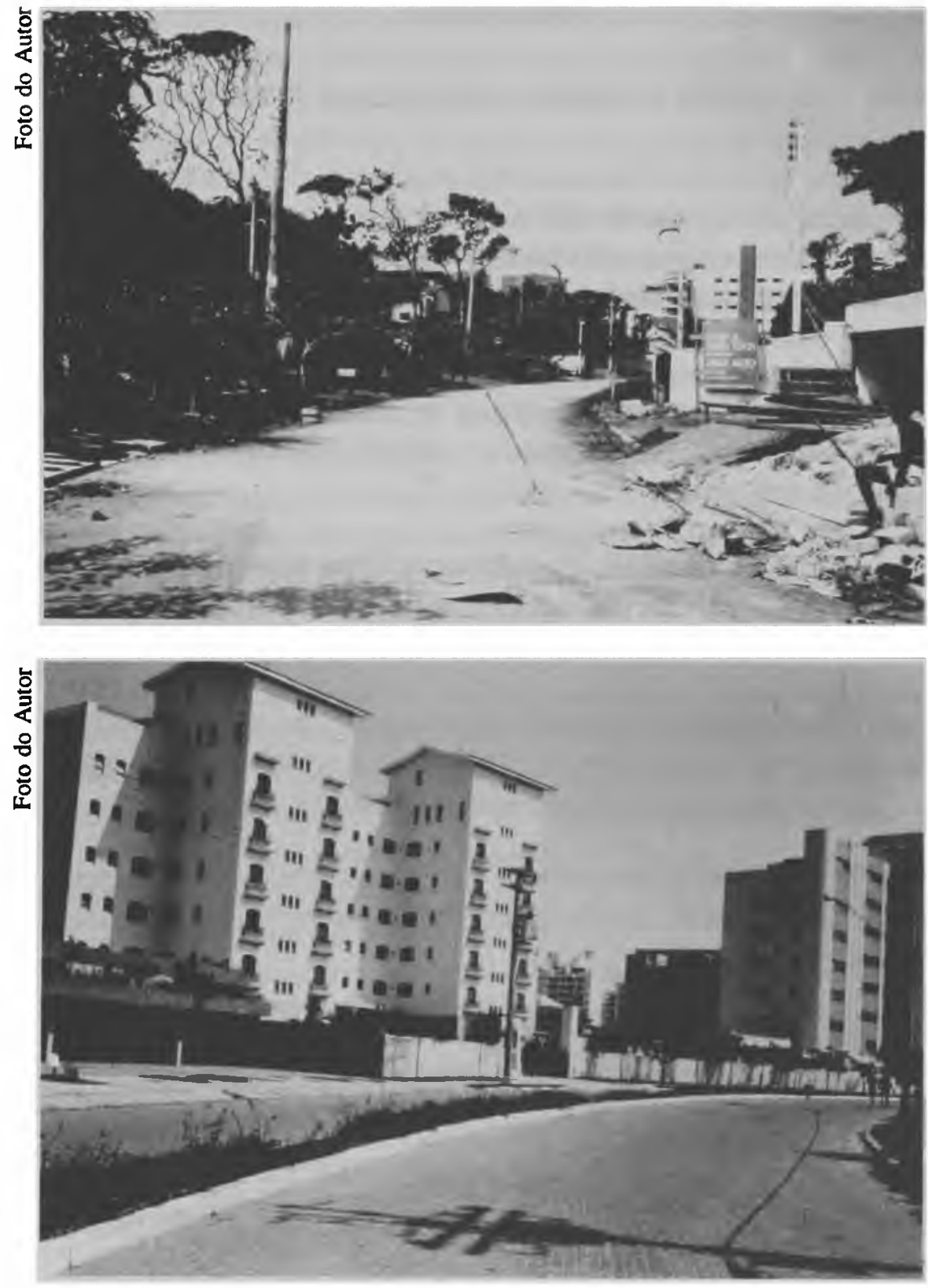

Bertioga, São Paulo: a Riviera de São Lourenço é o modelo urbanístico moderno transportado para uma regiāo de praia, causando graves danos à dinâmica ecológica local

Bertioga. São Paulo: no condomínio a vegetação nativa é substifuída para dar lugar a uma concepçāo urbanística tradicional, cujos expaçoss livres sāo organizados tal qual um hairro jardim convencional 


\section{CONCLUSÃo}

O espaço livre como elemento de projeto urbano é praticamente desconhecido pelos profissionais e pela população, que o vêem como um espaço residual a ser ajardinado ou simplesmente deixado de lado.

Esta sua importância para a configuração e usos urbanos só é percebida nos momentos de escassez e crise, quando o contexto urbano já está todo comprometido por construções e arruamentos e o seu fracionamento e dispersão é uma realidade. Parques, praças e demais espaços livres para lazer, ventilação, etc. são então praticamente impossíveis de serem constituídos, a menos que se envolvam para tanto recursos vultuosos, nem sempre acessiveis ao todo da comunidade.

Nos parece então urgente uma revisão no ideário sobre espaços livres e ações são fundamentais:

1. A afirmação e o aceite da existência real de um sistema urbano de espaços livres de edificação, que deve abarcar todos os espaços livres existentes, sejam eles espaços para lazer, ou circulação, verdes ou azuis, plantados ou não.

2. O abandono da idéia do "alcance" de metragens de metros quadrados por habitante como uma panacéia (incansável) aos problemas urbanos de carência de áreas de lazer e conservação de recursos ambientais, esquecendo-se definitivamente o malfadado índice de $12 \mathrm{~m}^{2 /}$ habitante de área verde.

3. O estabelecimento de critérios de distribuição de espaços livres públicos, que deve ser delimitado de acordo com carências sociais, acessibilidade e manutenção de recursos ambientais finitos, como água e florestas nativas e de proteção de solos frágeis.

4. O estabelecimento prévio ao crescimento urbano, as expansões das cidades de áreas prioritárias à construção e/ou efetivação de espaços livres, isto é, a criação e manutenção de estoques/reservas de futuros espaços livres públicos para lazer e conservação.

5. A revisão dos padrões de distribuição dos espaços livres intra-quadras, questionando-se os modelos oficiais, e seus graus de eficiência redefinindo-se os limites desejáveis (se desejáveis) de privatização do lazer.

6. A idealização de quadras urbanas, especialmente aquelas verticalizadas são sistemas complexos, onde flui a vida humana e cujos espaços livres devem ser tratados como sistemas que são, não como espaços residuais.

7. A revisão dos padrões de projeto dos espaços livres, que são extremamente padronizados para o país, buscando-se adequar cada um deles ao contexto do território nacional em que estiver situado. 
8. O reconhecimento do papel da rua como espaço de lazer e uma conseqüente revisão de seus padrões de desenho e projeto.

9. A inclusão das praias e áreas de beira-água (rios, lagos e represas) quando utilizados pela comunidade como participantes efetivos dos sistema de espaços livres de edificação urbanos e/ou como áreas de reserva para lazer e/ou conservação.

\section{NOTAS}

(1) "Na paisagem urbana essas expressōes físicas (no caso a autora se refere aos processos humanos) se manifestam sobre o solo em espaços edificados eespaços nãoedificados. OEspaço Livre é todo espaço não ocupado por um volume edificado (espaço-solo, espaço-água, espaçoluz ao redor das edificações a que essas pessoas têm acesso)"

Esta definição de Miranda Magnoli, serviu e serve de base para todo um desenvolvimento conceitual sobre os espaços livres urbanos dentroda área de Paisagismoda FAUUSP e seespalha pelos mais diversos pontos do país. Vide: MAGNOLI, Miranda M. E. Martinelli. "Espaços livres e urbanização: uma introdução aos aspectos da paisagem metropolitana", p. 48.

(2) "Pensar a cidade também pelos seus espaços livres de edificação, impantação e volumetria do edifício... seria anexar, de uma forma constante ao desenho da cidade, um fator fundamental o desenho dos espaços livres". MACEDO, Silvio Soares. "Os espaços livres de edificação e o desenho da paisagem urbana". In: TURKIENICZ, B. e MALTA, M. (org.) Desenho Urbano Anais do II SEDUR, p. 103.

(3) Notas de aula. A formulaçãode programade disciplinas e discussōes conjuntas com Miranda M. Magnoli, mais que textos e entre estes principalmente a tese referida na nota 1 nos serviram de embasamento conceitual para a formulação destes conceitos sobre espaços livres.

(4) O professor Felisberto Cavalheiro (FFLCH-USP-Geografia) há alguns anos fez uma consulta formal à $\mathrm{ONU}$ e não recebeu nenhuma confirmação sobre a existência do Índice.

(5) Miranda Magnoli em sua tese de livre-docência e no texto "O Parque no desenho urbano" nos mostra graficamente que os bairros-jardins de São Paulo, densamente arborizados, são muito maiores que os grandes parques da cidade. $O$ bairro da Chácara Flora, poderia conter ao menos dois parques Ibirapuera (o mais importante, socialmente falando, da cidade) e o bairro de Interlagos poderia conter folgadamente o Parque do Carmo. Vide MAGNOLI, Miranda Martinelli. "O parque nodesenhourbano". In: TURKIENICZ, B.e MALTA,M.(org.) Desenho Urbano - Anais do II SEDUR, pp. 111-120.

(6) Esta pesquisa deu origem à dissertação de mestrado "Espaços livres junto às habitaçōes em São Paulo"defendida na FAUUSP em 1984, da qual extraimos a tabela em questão.

(7) Em nosso cotidiano como professor de paisagismo em Escolas de Arquitetura e Urbanismo (UFSC - 1980/1982 e FAUUSP - 1976... 1984...) temos aplicado exercícios que visam á leitura dos usos dos espaços livres públicos junto à habitação, tendo já analisado mais de 500 casos diversos, tanto em São Paulo como em Florianópolis, o que observamos foi uma repetição de situações-padrão de uso, que nos levaram às conclusões explicitadas no texto. 
(8) Os estudos arquitetônicos do início do século XX, repudiados ostensivamente durante as décadas de 50,60 e 70, são reavaliados e incorporados ao ideário social de bem viver. O "Art deco" da vila, um estilo de transição para o moderno é, como muitos outros, considerado nos anos 80 e 90, arquitetonicamente correto.

(9) Ver para maior aprofundamento nas questões e princípios do projeto paisagístico de logradouros públicos no Ecletismo (do século XIX e XX) a tese de doutorado de Hugo Segawa, intitulada "Ao amor do público", defendida na FAUUSP em 1994.

(10) A obra de Burle Marx é a única, entre a dos paisagistas nacionais, que está amplamente divulgada e documentada tanto a nível nacional como internacional, destacando-se entre os textos nacionais o de Pietro M. Bardi e o de Flavio Motta.

(11)Vide para introdução à questão dos textos de Marcos Castilha e Omar Cardoso sobre os paisagistas modernos em São Paulo, na publicação Paisagem e Ambiente - Ensaios IV da FAUUSP.

(12) As formas e padrões espaciais adotados por toda uma linha projetual brasileira, devido a sua estreita ligação como paisagismo americano californiano, pode de certo modo ser observada nos esquemas gráficos apresentados por Grant Reid em seu livro "From Concept to form in Landscape Design. Poucos são os trabalhos dedicados à análise destas correntes projetuais e podemos no caso destacar a pesquisa de Francine Gramacho sobre os projetos de jardim contemporâneo em prédios de apartamentos na cidade de São Paulo, desenvolvido na FAUUSP de 1993 a 1994.

(13) Para uma introdução ao trabalho destes autores vide: Anais do I e II SEDUR, publicados respecivamente pelas Editoras Projeto e Pini.

(14) Para melhor entendimento destas hierarquias vide o texto de Eurico Salviati publicado na Revista Sinopses n. 11, intitulado "Os espaços livres urbanos de Brasília - uma avaliação preliminar"

(15) Leia-se o texto de Décio Rigatti "Apropriação Social do Espaço Público - um estudo comparativo". In: Paisageme Ambiente - Ensaios 7, que mostra estas transformações dentro do Conjunto Habitacional de Carapicuíba no Estado de São Paulo.

(16) A conformação destes espaços está diretamente ligada às formas de organização espacial intra-lote adotadas dentro do contexto urbano brasileiro. Para maiores informações sobre a cidade de São Paulo vide as teses de doutorado de Silvio Macedo: "São Paulo, Paisagem e Habitação Verticalizada", e de Cibelle H. Taralli: "Ambiente construído e legislação - o visível e o imprevisível"

(17) Nestor Goulart Reis Filho em seu texto "Quadro de Arquitetura no Brasil" e Maria Cecília N. Homem, em sua tese de doutorado, mostram claramente a evolução e oinício deste processo. (18) Idem nota 16.

(19) Quando fizemos nossa tese de livre-docência intitulada "Paisagem, Litoral e Urbanismo do Éden à Cidade", tivemos a oportunidade de estudar os padrões de loteamento em mais de 40 municípios brasileiros em três estados com áreas costeiras, constituídas de múltiplos ecossistemas e sobre as quais detectamos a implantação constante destes tipos de loteamentos.

(20) Vide o texto de Holanda, Frederico: "Arquitetura como construção social" para um aprofundamentoinicial em tais questões de privatização e segmentação social do espaçourbano. 


\section{BIBLIOGRAFIA}

ASHIHARA, Y. Exterior design in architecture. New York: Van Nostrand Reinhold, 1970.

BARDI, Pietrom. Tropical gardens of Burle Marx. Amsterdam: RJ, Colibris Editora, 1964.

CULLEN, Gordon. El paisagem urbano. Tratado de estética urbanística. Barcelona: Blume, 1977.

GRAMACHO, Francine S. Relatório final de pesquisa - FAPESP. São Paulo: FAUUSP, 1994.

HOLANDA, Frederico. Arquitetura como construção social. In: $O$ espaço da cidade contribuição à análise urbana. São Paulo: Projeto, 1988.

HOMEM, Maria Cecília N. O palacete paulistano. São Paulo, 1992. Tese (Doutorado) Faculdade de Arquitetura e Urbanismo, Universidade de São Paulo.

LEITE, Maria Angela Faggin Pereira. Destruiçāo ou desconstrução. São Paulo: Hucitec/ FAPESP, 1994, 117p.

LYNCH, K. A imagem da cidade. Lisboa: Edições 70, 1980.

MACEDO, Silvio Soares. (editor). Paisagem e Ambiente - Ensaios, n. 3, 2ª ed., São Paulo: FAUUSP, 1993,

O bairro de higienópolis e arredores. São Paulo: EDUSP/PINI, 1987, ilustrado.

. São Paulo, paisagem e habitação verticalizada-Os espaços livres como elementos de desenho urbano. São Paulo, 1987. Tese (Doutorado) Faculdade de Arquitetura e Urbanismo, Universidade de São Paulo.

MAGNOLI, Miranda M. E. M. Espaços livres e urbanização: Uma introduçāo à aspectos da paisagemmetropolitana.SãoPaulo, 1983. Tese(Livre-Docência)-FaculdadedeArquitetura e Urbanismo, Universidade de São Paulo.

MOTTA, Flavio L. Roberto Burle Marx e a nova visão da paisagem. São Paulo: Nobel, 1984.

NISHIKAWA, Ayako. Espaços livres junto à habitação. São Paulo, 1984. Dissertação (Mestrado) - Faculdade de Arquitetura e Urbanismo, Universidade de São Paulo.

REID, Grant W. From concept to form in landscape design. New York: Van Nostrand Reinhold, 1993. 
REIS FILHO, Nestor G. Quadro da arquitetura no Brasil. São Paulo: Perspectiva, 1970.

RIGATTI, Décio. Apropriação social do espaço público - Um estudo comparativo. Trabalho apresentado para a disciplina de pós-graduação AUP-810 "Paisagismo" São Paulo, FAUUSP, 1993.

SALVIATI, Eurico. Os espaços livres urbanos em Brasília-Uma avaliação preliminar. São Paulo. Sinopses 11, dez. 1988.

SEGAWA, Hugo. Ao amor do público - jardins do Brasil 1779-1911. São Paulo, 1994. Tese (Doutorado) - Faculdade de Arquitetura e Urbanismo, Universidade de São Paulo.

TARALLI, Cibele H. Ambiente construido e legislação - o visível e o imprevisivel. São Paulo, 1994. Tese (Doutorado) - Faculdade de Arquitetura e Urbanismo, Universidade de São Paulo.

TURCKIENCZ, B. et al (org.) Desenho urbano. In: Cadernos Brasileiros de Arquitetura. São Paulo: Projeto, 1984, v. I, II e III.

TURCKIENICZ, B.; MALTA, M. (editores). Desenho Urbano. In: SEMINÁRIO SOBRE O DESENHO URBANO NO BRASIL. 2, São Paulo. Anais. São Paulo: Pini/CNPq/FINEP, 1986, 392p. 